\title{
IILGARDIA
}

OURNAL OF AGRICULTURAL SCIENCE PUBLISHED BY

IE CALIFORNIA AGRICULTURAL EXPERIMENT STATION

Volume 52 - Number 4 March 1984

31175013793594

\section{Ecology of a}

\section{Blackberry-Leafhopper-Parasite}

System

\section{and its Relevance to}

California Grape Agroecosystems

D. W. Williams 


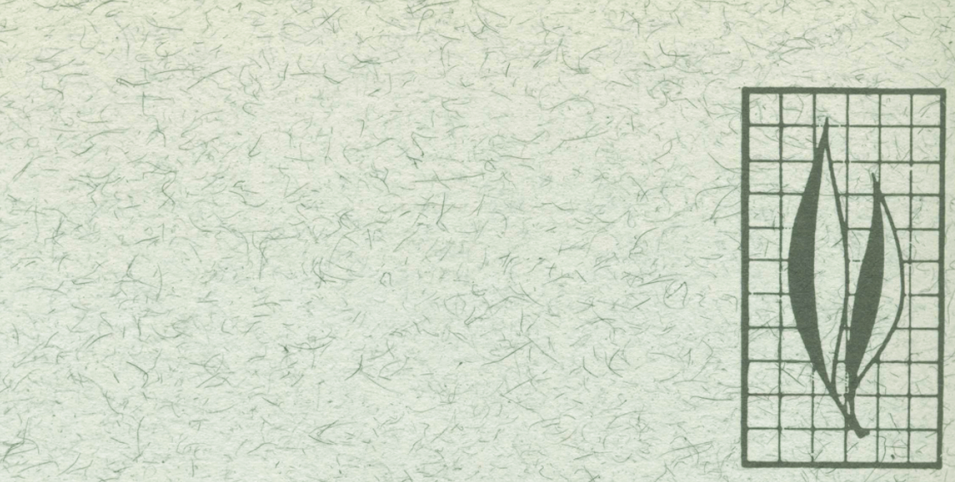

Natural ecosystems are often sources of pest arthropods and their natural enemies for nearby agroecosystems. This study treats the ecology of the native California blackberry, Rubus ursinus Cham. and Schlecht, and an imported blackberry, Rubus procerus P.J. Mueller, the blackberry leafhopper (BLH), Dikrella californica (Lawson), and its egg parasite, Anagrus epos Girault, in two riparian habitats and a vineyard site. Anagrus is also an effective natural enemy of the grape leafhopper (GLH), Erythroneura elegantula Osborn, which evolved on wild grape in the riparian habitat and became a serious pest after the introduction of commercial varieties.

The parasite overwinters in immature stages in the eggs of BLH in blackberry. In the early spring, growth of the native blackberry and BLH oviposition precede grape growth and GLH oviposition by the length of one parasite generation. Since Anagrus becomes active when BLH oviposition begins, this synchrony allows the parasite to increase its populations in the riparian refuge before entering the vineyard.

The two blackberry species differ in their preferred habitats: the native blackberry is limited to moist shady habitats, while the imported species grows in open sunlit areas. In phenology the imported blackberry appears less synchronized with and less constrained by the California climate. The blackberry leafhopper produces three generations per year and overwinters as a diapausing adult. The leafhopper is well adapted to the phenology of the native blackberry, but less so to that of the imported species, which breaks dormancy in the spring long after BLH terminates diapause. Leafhopper females oviposit primarily in the lower half of the leaf canopy of the native blackberry throughout the season, while in the imported species they shift oviposition from the top of the canopy in early spring to the bottom by late summer.

A time-varying life table analysis shows that BLH immature mortality due to Anagrus, nymphal parasites, and general predators is positively density dependent. Age-specific tife table analyses in the laboratory estimate that Anagrus' intrinsic rate of increase $\left(\mathrm{r}_{\mathrm{m}}\right)$ is 2.2 times those of BLH and GLH. Although $r_{m}$ is a questionable index of parasite effectiveness, the difference probably allows Anagrus to respond rapidly to changes in GLH populations. Suggestions for the further augmentation of Anagrus populations in artificial refuges includes the management of blackberry and the monitoring and maintenance of BLH populations.

\section{THE AUTHOR:}

D. W. Williams is Systems Analyst/Modeler, University of California Statewide Integrated Pest Management Project. 


\section{Ecology of the}

\section{Blackberry-Leafhopper-Parasite System and Its Relevance to}

\section{California Grape Agroecosystems ${ }^{1}$}

\section{Introduction}

Agroecosystems and natural ecosystems often share herbivorous arthropods and their natural enemies. Grape provides an example, as both cultivated grape and wild grape in riparian habitats are attacked by the grape leafhopper (GLH), Erythroneura elegantula Osborn. Grape leafhopper is attacked in turn by a complex of natural enemies that also attack other leafhopper species, including the blackberry leafhopper (BLH), Dikrella californica (Lawson). The egg parasite Anagrus epos Girault (Hymenoptera: Mymaridae) is a very effective natural enemy of both leafhopper species.

Anagrus was discovered in California vineyards in the 1930s (Lockwood, 1932). Doutt and Nakata $(1965,1973)$ first observed that GLH control by Anagrus was good in vineyards near natural riparian habitats and suggested that the egg parasite could be a successful control agent. Poor control was seen often in vineyards distant from natural habitats because GLH overwinters as a diapausing adult and host eggs are not available for Anagrus overwintering. Doutt and Nakata proposed augmenting natural control by planting blackberry near vineyards and hence providing Anagrus an overwintering host in the blackberry leafhopper. Blackberry patches serve both as hibernation "refuges" for Anagrus and as areas for parasite population buildup in the early spring, since BLH begins ovipositing earlier than GLH.

Anagrus epos also has been reported to attack several other leafhopper species (Krombein et al., 1979 and Mulla, 1956). In Canada, McKenzie and Beirne'(1972) found A. epos effective in controlling a grape-feeding leafhopper Erythroneura ziczac Walsh and suggested augmenting natural control by planting wild rose and apple to harbor the rose and apple leafhoppers, which are overwintering hosts of the parasite.

In the following sections, I investigate the ecology of the blackberry-leafhopper-parasite system, beginning with a study of the phenology and growth patterns of Rubus ursinus Cham. and Schlecht, the California blackberry, and $R$. procerus Mueller, the imported Himalaya blackberry. I then report on field studies of BLH populations at three northern California sites, including work on population dynamics, overwintering diapause, and interactions with Anagrus and other parasites. This is followed by a field life table analysis and a study of the relationship of BLH oviposition to blackberry canopy structure. Next, I report the results of laboratory studies of Dikrella and Anagrus, and present age-specific life tables for both species. I conclude with a discussion of the ecology of the system with emphasis on its implementation in artificial refuges in the grape agroecosystem. 


\title{
MATERIALS AND METHODS
}

\author{
Study Sites
}

Studies were conducted at three northern California sites: on the Sacramento River 10 miles north of Sacramento, in Strawberry Canyon in the Berkeley hills overlooking the University of California campus, and at Oakville in the Napa Valley. The Sacramento and Strawberry Canyon sites are both located in riparian habitats containing typical assemblages of native plant species (q.v., Barbour and Major, 1977), including Rubus ursinus, the California blackberry. This blackberry was the dominant Rubus species in both riparian sites. At the Sacramento site, the blackberry grew vigorously as an understory plant in an area dominated by old, dying cottonwoods (Populus fremontii) with sparse canopies. In Strawberry Canyon, on the other hand, $R$. ursinus was shaded for much of the day by oaks (Quercus spp.), alders (Alnus rhombifolia), and bay laurels (Umbellularia californica) and grew less vigorously.

At the Oakville site, patches of Rubus procerus, the imported blackberry, grew wild in a pasture adjacent to commercial vineyards. Additionally, the growth habits of $R$. procerus were studied in a wild patch which grew along a creek on the grounds of the University of California Gill Tract in Albany.

\section{Rubus Growth}

Observations on the growth phenology of the blackberry species were made at all locations from January 1979 through June 1980. Special attention was paid to the flowering cycles of the plants. Records of canopy depths were also made as part of a stratified egg-nymph sampling study described below.

A systematic study of leaf area accumulation, node production, and cane density was undertaken: specifically, the average axial node accumulation rate per cane as a function of physiological time, mean leaf area per axial node, and average number of canes originating per $\mathrm{m}^{2}$ of blackberry bramble were estimated. These parameters were estimated to build a simple model of leaf surface area production per $\mathrm{m}^{2}$ of patch as a function of physiological time.

\section{Estimating Leaf Area and Node Accumulation}

Areas of all leaves in the experiments were determined by comparing sampled leaves with series of photocopied leaves of known area. A standard series was prepared for each blackberry species by weighing photocopies of leaves and determining their areas by dividing by the weight per $\mathrm{cm}^{2}$ of copy paper.

In blackberry brambles, individual plants are difficult to distinguish, so vegetative canes (primocanes) were chosen as the basic sample units. Figure 1 illustrates the biennial growth cycle of a single blackberry cane (as elaborated in Bailey, 1945). Node accumulation rates were assessed by tagging 20 to 30 cane apices with $10 \mathrm{~cm}$ lengths of colored polyethylene flagging tape. Primocanes generally were chosen for tagging, although some vigorously growing lateral shoots were also tagged in studies on $R$. procerus. Canes were observed at regular intervals over 3 to 4 week periods and new nodes were counted as they grew beyond the tags. At the end of an observation period, the canes were severed below the 
tags and taken to the laboratory where leaf surface areas were estimated. Tagging experiments on each Rubus species were performed three to four times: twice in the late spring or early summer when their growth rates were maximal, and once or twice in the late summer or fall when their rates were declining.

In the more mature Albany site, there were many floricanes present, necessitating the estimation of leaf areas for floral laterals. Since no nodes and leaves are added after flowering, the growth of floral shoots is very predictable. To obtain a mean leaf area per floral shoot, 20 shoots were clipped at random, and their total leaf areas were estimated.

\section{Cane Densities}

At the Sacramento and Albany sites, densities of newly emerging primocanes, and sterile and inflorescence-bearing laterals were obtained for both species during the late spring of 1980 by placing a $0.25 \mathrm{~m}^{2}$ quadrant at random over the canopy. At the Sacramento site, $R$. ursinus cane densities were counted on five dates, from the time the canes first emerged from the ground until they began to arch and grow horizontally. Throughout the season, the profusion of canes in the brambles made sampling difficult.
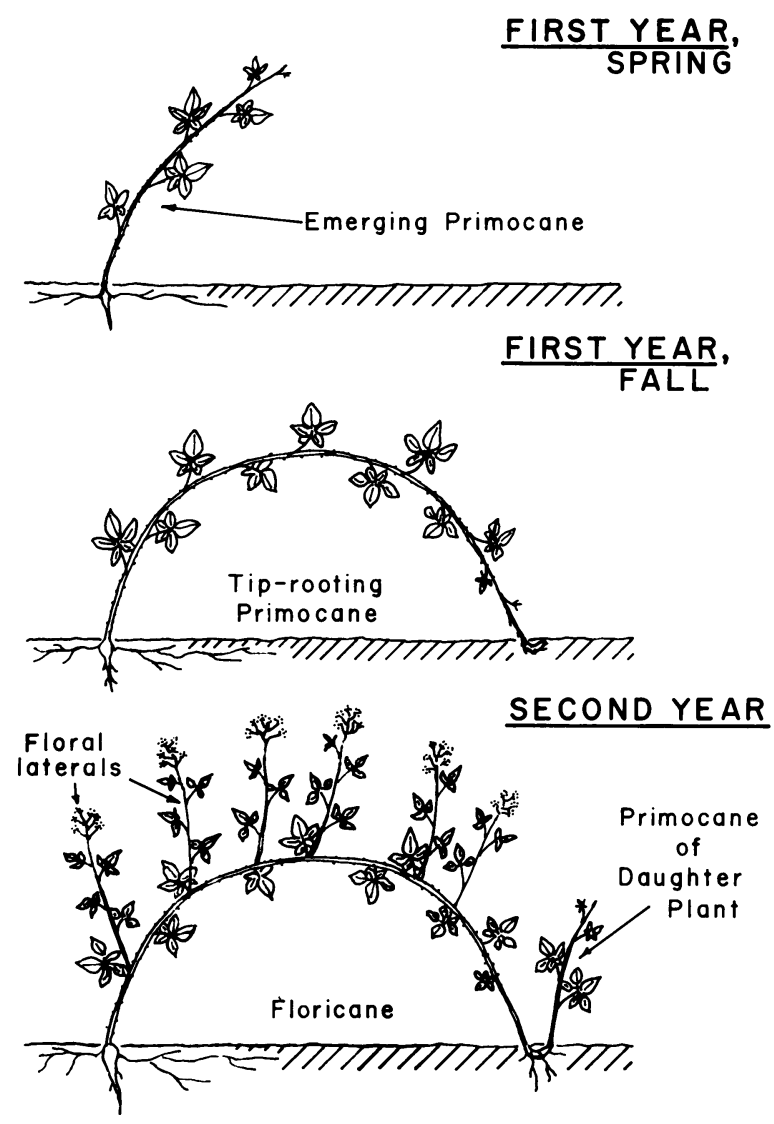

Fig. 1. The biennial cane cycle of blackberry (Rubus spp.). Top, primocane (first year) arising from perennial rootstock in spring. Middle, tip-rooting primocane entering dormancy in fall. Bottom, floricane (second year) with floral laterals arising from axial nodes. A new primocane is shown growing from the daughter plant that resulted from tip-rooting. 


\section{Field Studies}

\section{Sampling of Blackberry Leafhopper Eggs and Nymphs}

Dikrella immatures were monitored at 1 to 3 week intervals by leaf sampling. From July 1978 to April 1979, samples consisted of 10 to 20 compound leaves; after this time, each sample consisted of 120 terminal leaflets. Rubus ursinus has three leaflets per compound leaf, while $R$. procerus has three, four, or (most commonly) five. In both species, the terminal leaflet is the large center-most leaflet opposite the petiole. Starting in April 1979 , samples were taken in four strata in the blackberry canopy. A pointed wooden pole equipped with a sliding metric scale was placed randomly into the foliage to measure canopy depth. The lower end of the scale was pushed to the bottom of the canopy; the canopy depth was divided into four equal parts; and one leaf was clipped at random from the lowest, one-third, two-thirds, and highest points (four leaves in all). Thirty 4-leaf samples (120 leaves) were collected at the Sacramento and Oakville sites on each date. Typical samples at the Strawberry Canyon site consisted of 30 to 60 leaves taken at random throughout the canopy. Eggs were dissected from leaf tissue under a microscope and placed in one of the following categories: 1) early leafhopper egg; 2) late leafhopper egg (with the red compound eye visible); 3 ) early (white) parasite larva; 4) late (red) parasite larva; 5) parasite pupa; or 6) parasite pharate adult. Nymphs were identified by instar with a hand lens and counted in the field.

\section{Monitoring of Blackberry Leafhopper Adults}

Adult blackberry leafhoppers were monitored with sticky traps. This sampling method gave only qualitative assessments of adult population trends, but was chosen over other methods such as sweeping or suction sampling both because blackberry has many thorns, which make it difficult to sample, and because these methods destroy the foliage and disrupt the leafhopper populations. Traps made of two 3-quart food cans bolted together and painted yellow were mounted on wooden stakes. The can frame was covered with a clear polyethylene bag that was coated lightly with Stickem Special using a paint roller. Initially, the traps were mounted so that half their lengths were in the canopy, although later, in some cases, the bramble grew up so as to engulf individual traps. Four traps were placed per site, spaced about $15 \mathrm{~m}$ apart in a straight line or alternately in a T-shaped pattern. Used traps were replaced with fresh ones at 1 to 3 week intervals and were returned to the laboratory, where the trapped hoppers were identified and counted. In addition, the adults of Paraproba pendula Van Duzee, a predatory mirid, were counted at Strawberry Canyon.

\section{Diapause and Parasitization of Blackberry Leafhopper Adults}

To investigate the reproductive states and parasitization levels of overwintering leafhoppers, adults were collected from October to February during the 2-year study. Generally, 20 to 40 adults were aspirated from the undersides of blackberry leaves and returned live to the laboratory for dissection to determine their reproductive states and whether they were parasitized. Females were classified as: 1) diapausing (no ovariole development), 2) intermediate (ovarioles extended, with immature eggs present), 3) gravid (one or more mature eggs), or 4) parasitized. Parasitization, as evidenced by the presence of dryinid sacs externally at the anterior of the abdomen or of pipunculid larvae internally, was recorded. 


\section{Laboratory Studies of the Blackberry Leafhopper and Anagrus epos}

Temperature-dependent growth rate studies were conducted at constant temperatures by enclosing BLH and Anagrus in standard leaf cages (fig. 2). Because of the small size of Anagrus, cages used in parasite experiments were modified by replacing the nalgene screen ventilation port covers with covers of a fine mesh nylon organdy. Rubus procerus cuttings obtained from a bramble patch at the Gill Tract were grown in natural soil in 5-gallon tins and served as the standard host plants in all laboratory experiments. This species was selected for convenience, since Rubus ursinus grew poorly in both the greenhouse and temperature cabinets. This study does not address the question of nutritional differences between the two Rubus species. Hence, it is possible that BLH growth and fecundity patterns may differ on the two host plants.

\section{Immature Developmental Rates, and Adult Longevity and Fecundity of the Blackberry Leafhopper}

In the immature developmental rate study, five to six mature females were caged together on the underside of a leaf and allowed to oviposit for 24 hours at room temperature (ca $23^{\circ} \mathrm{C}$ ). The hoppers then were removed and the plants were placed randomly in

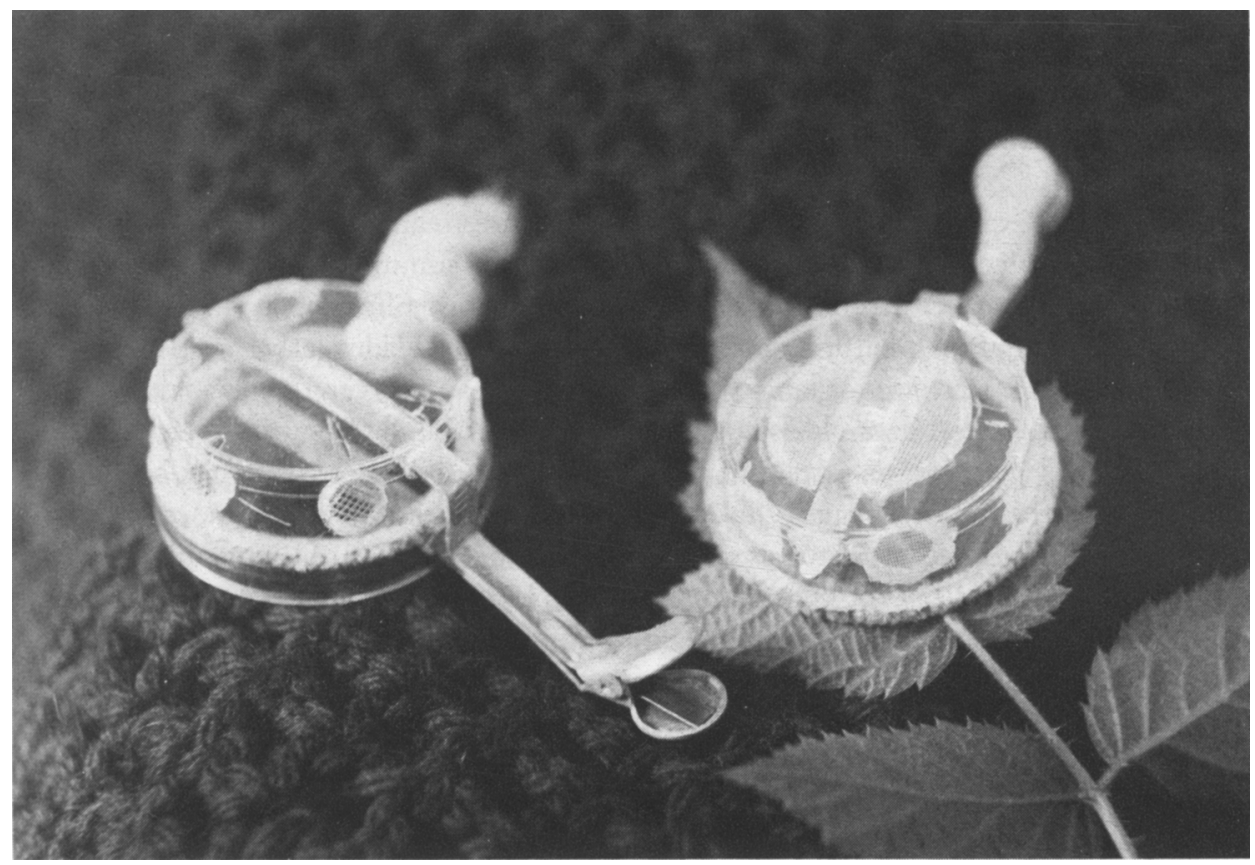

Fig. 2. Clip cages used in laboratory studies of development, and fecundity and longevity of the blackberry leafhopper (left) and Anagrus (right). 
constant-temperature chambers set at $13.2^{\circ}, 20.2^{\circ}, 24.1^{\circ}, 27.9^{\circ}$, and $30.0^{\circ} \mathrm{C}$. The caged eggs and hatched nymphs were observed at 12 -hour intervals through adult eclosion. In the fecundity and longevity study, 16 newly eclosed females were caged with males at each of three temperatures $\left(20^{\circ}, 24^{\circ}\right.$, or $\left.28^{\circ} \mathrm{C}\right)$. Females were moved to fresh leaves at 3-day intervals and their eggs in the old leaves were counted. A long-day photoperiod (15L:9D) was used in all experiments.

\section{Feeding Rate of the Blackberry Leafhopper}

Blackberry leafhoppers feed on leaf mesophyll tissue, sucking out the contents of cells as they probe (Delong, 1965). Under the microscope, the damage appears as a circle of yellow, empty cells surrounded by a narrow halo of dying, ruptured cells. The gross appearance of damage is a yellow stippling on the dark green upper surface of a leaf. Thus, the main effect of BLH on its host plant is the destruction of photosynthetic area. The damage is quite visible and the area of leaf surface killed by an individual hopper during a given period was estimated in the following manner. Mean surface area removed for the entire nymphal period was determined by rearing 22 newly emerged first instars to adulthood in individual cages in the greenhouse $\left(\mathrm{ca} 25^{\circ} \mathrm{C}\right)$. To estimate the daily feeding rates of adults as a function of temperature, adults were caged individually for 5 days at $18^{\circ}$ and $23^{\circ} \mathrm{C}$ and 3 days at $28^{\circ} \mathrm{C}$ on separate sets of leaves. The damaged leaves were photographed and high contrast prints of them were made. Since individual damage spots were uniform in size and approximately circular, the mean damage area of a spot was estimated from measurements of the diameters of 66 nymph and 108 adult spots using a reticule eyepiece in a dissecting microscope. Leaf damage was estimated by multiplying the total number of damage spots per leaf by the mean damage area per spot.

\section{Parasite Studies}

All laboratory experiments with Anagrus used parasites reared from GLH eggs on grape or BLH eggs on blackberry that were collected during the summer of 1980 at the Oakville site. Parasites were reared from the leaf discs kept on moist filter paper in petri dishes at room temperatures. Stock cultures of blackberry with BLH egg-laden leaves were maintained in the greenhouse. Care was taken to assure that eggs exposed to Anagrus females were never more than 3 to 4 days old, since it is known that the developmental period of the parasite in eggs reaching an advanced state of embryonic development may be up to 4 percent longer than in early eggs (Otake, 1968). Female parasites were removed from the petri dishes with a small aspirator as they emerged and were exposed immediately in clip cages to host eggs at one of three temperatures $\left(18^{\circ}, 23^{\circ}\right.$, or $\left.28^{\circ} \mathrm{C}\right)$. Food for each parasite was supplied as a thin stripe of dilute honey painted onto the wall of its cage. Whether a female mated or not depended upon the coincidence of emergence of the two sexes on a given day, but overall approximately 60 percent of all females in the experiments mated (that is, if only male progeny resulted, a female was assumed not to have mated). Females were exposed to fresh batches of host eggs daily. Leaves exposed to parasites were placed in petri dishes on moist filter paper, where Anagrus were reared. The parasitized eggs were checked daily for Anagrus developmental stage or adult emergence. Data from parasite females that were injured or killed during the course of the experiments were not included in the life table analyses. 


\section{Analysis and Weighting of Data}

Before computing statistics on immature densities in the field study, all samples were standardized to a unit leaf of $30 \mathrm{~cm}^{2}$; hence leaf counts were multiplied by 30 and divided by individual leaf areas. Means and standard deviations were computed for the 120-leaf samples, under the assumption of equal leaf densities in the four canopy levels. (The assumption of evenness of distribution may be questionable, because no data were taken on the relative densities of leaves in the four strata.)

In constructing life tables from the laboratory data, intrinsic rates of increase and net reproduction rates were calculated using a program written by A. P. Gutierrez. By using successive approximations from an initial estimate, the program finds an $r_{m}$ that satisfies the Lotka (1925) equation

$$
\int_{x=0}^{\infty} e^{-r_{m} x} 1_{x} m_{x} d x=1 .
$$

All statistical analyses were performed on a Data General Eclipse 130 minicomputer located in the laboratory of A. P. Gutierrez at the UC Division of Biological Control. The Monitor interactive statistical package used was modified by G. E. Smith (University of California) from programs written originally by N. E. Gilbert (University of British Columbia).

\section{RESULTS \\ Blackberry Growth and Phenology}

\section{Seasonal Patterns}

The phenology of canopy development, flowering, berry production, and dormancy for Rubus ursinus and $R$. procerus in 1979 are shown in figures 3 and 4, respectively. The data are plotted on physiological time $\left({ }^{\circ} \mathrm{D}\right)$ above the lower threshold for $\mathrm{BLH}$ development $\left(8.12^{\circ} \mathrm{C}\right)$. This threshold was selected because it was below the lowest temperatures generally encountered in the plant growth rate studies and also because it was convenient for plotting the data of BLH population dynamics.

In both species there is a rapid growth of canes in early spring to produce a maximum canopy height of 50 to $60 \mathrm{~cm}$. The height decreases late in the season due to both a compaction of canes (by gravity, wind, etc.) and a loss of leaves in the lower strata as a result of moisture stress, shading, and senescence. The flowering and fruiting frequency curves are qualitative, and were constructed from field notes.

In 1979 total reproductive periods in ${ }^{\circ} \mathrm{D}$ above $8.12^{\circ} \mathrm{C}$ were similar in length for Rubus ursinus $\left(1265^{\circ} \mathrm{D}\right)$ and $R$. procerus $\left(1339^{\circ} \mathrm{D}\right)$. The species differed in their timing of reproduction, with $R$. ursinus beginning to produce flowers and fruit early in the year and $R$. procerus, later. Rubus ursinus was observed to flower from March 29 to June 27 ( 84 to $860{ }^{\circ} \mathrm{D}$ ), while $R$. procerus flowered from May 20 to June $30\left(469\right.$ to $953{ }^{\circ} \mathrm{D}$ ). Berries were first observed in $R$. ursinus on April $18\left(177^{\circ} \mathrm{D}\right)$ and the last berries were 
ripe by August $1\left(1339^{\circ} \mathrm{D}\right)$. In $R$. procerus the first berries were produced on June 20 $\left(858^{\circ} \mathrm{D}\right)$ and the last ripened by September $5\left(1265^{\circ} \mathrm{D}\right)$.

Field observations made in 1979 suggest that $R$. procerus produces a much higher biomass of berries per unit bramble area than does $R$. ursinus. This comparison should be regarded with caution as a reflection of species differences, since the two species grew (and generally are found) in different habitats: $R$. procerus grew in an open sunny pasture, while $R$. ursinus grew in the understory. It is known from studies on other Rubus species (Abrahamson, 1975) that plants growing in sunny habitats allocate more biomass to flowers and fruit, and less to leaves and stems than plants growing in shaded habitats. This phenomenon was observed qualitatively for $R$. ursinus at the Sacramento (partially shaded) and Strawberry Canyon (heavily shaded) sites: flowers and fruit were present at Sacramento, while they were seen only rarely at Strawberry Canyon.

In both species, the growth season appears to end when moisture stress sets in. This is indicated by the decline in canopy height in mid-August (1500 to $\left.1670{ }^{\circ} \mathrm{D}\right)$, as shown in

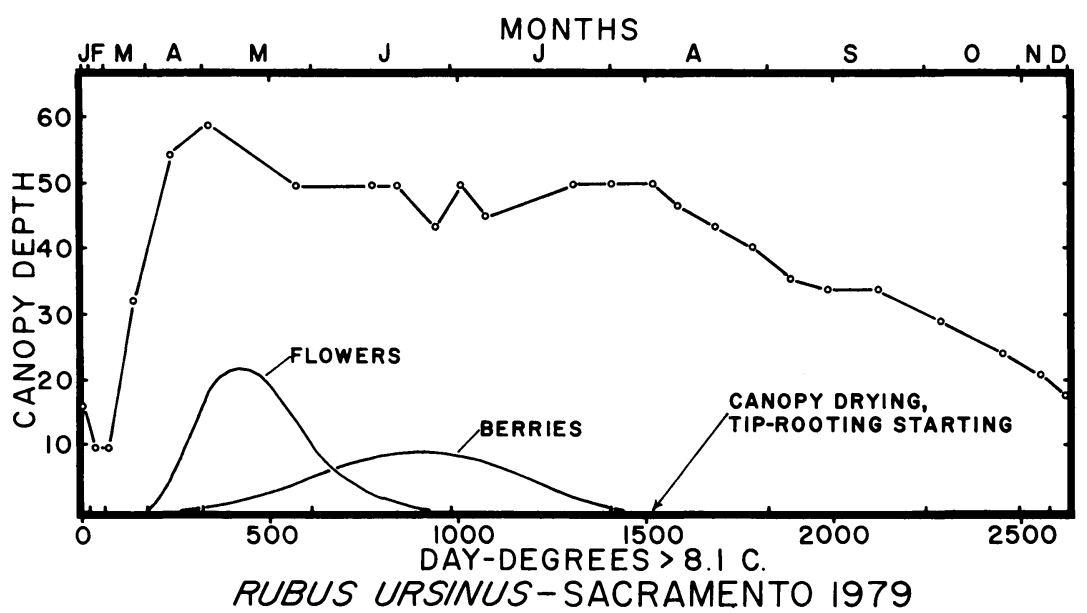

Fig. 3. Phenology of Rubus ursinus at Sacramento in 1979. Open circles are depths of the leaf canopy (in $\mathrm{cm}$ ) throughout the year. Lower curves are subjective estimates of flower and berry abundance.

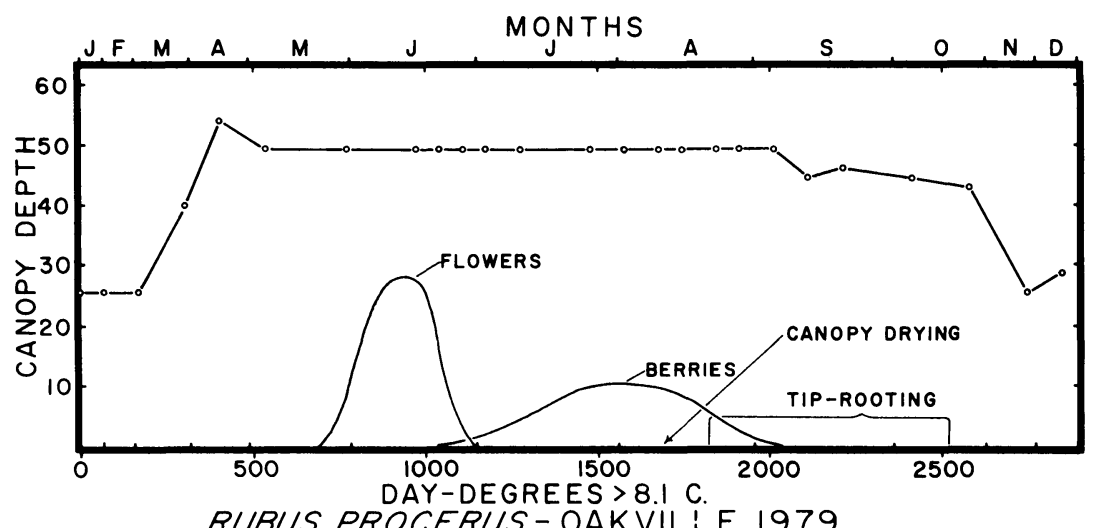

Fig. 4. Phenology of Rubus procerus at Oakville in 1979. Open circles are depths of the leaf canopy (in $\mathrm{cm}$ ) throughout the year. Lower curves are subjective estimates of flower and berry abundance. 
figures 3 and 4 . Generally cane growth slows and drying begins at the bottom of the canopy: leaves die at the lowest canopy stratum until only a thin outer shell of leaves is left by the beginning of the next season. In preparation for dormancy, $R$. ursinus begins primocane tip-rooting in mid-August, while tip-rooting occurs from late August through late October in $R$. procerus.

In $R$. procerus the dormant period, determined both from field and greenhouse observations, is from late November to late January. The growth characteristics both outdoors and in a heated greenhouse were similar, suggesting that dormancy cues are photoperiodic. During the dormant period, both species retain many of the previous season's primocane leaves in a reddened, leathery condition. Bud break was first observed in both species at all locations on the same sampling date (March 7), even though fewer ${ }^{\circ} \mathrm{D}$ were accumulated $\left(77^{\circ} \mathrm{D}>8.12^{\circ} \mathrm{C}\right)$ for $R$. ursinus at Sacramento than for $R$. procerus at Oakville $\left(192^{\circ} \mathrm{D}\right)$. Bud break for $R$. procerus was observed at about $195^{\circ} \mathrm{D}$ in Albany. These observations reinforce the idea that termination of dormancy is under photoperiodic control and that the thresholds for the two species are similar.

\section{Node Accumulation}

Means, standard deviations, and coefficients of variation (CV) for nodes accumulated per cane, leaf area per cane, compound leaf area per node, and leaf area indices are listed in table 1 for the two Rubus species. In figures 5a, 5b, 6a, 6b, and 6c, regression lines for node accumulation on ${ }^{\circ} \mathrm{D}$ during the season are superimposed on the observed data points. Node accumulations of individual primocanes are indicated by thin lines, and illustrate the variability in cane growth rates. The heavy dashed line in figure $5 c$ connects the origin to the final node accumulation mean and is not a regression line, because no intermediate node counts were made. The figure was provided so that the growth patterns for the two blackberry species might be compared during the three time periods. Early season observations were not made on both species concurrently because of the distances between study sites. Growth rates for $R$. procerus were estimated after canopy development was well underway. Hence, the comparisons between the two species are qualitative.

The rate of growth of Rubus ursinus canes during the first part of the season was 0.028 to 0.037 nodes per ${ }^{\circ} \mathrm{D}$. This slowed dramatically toward autumn to a rate of 0.007 to 0.011 . Rubus procerus, on the other hand, grew more slowly and evenly throughout the season, with rates of 0.016 to 0.022 nodes per ${ }^{\circ} \mathrm{D}$. Figure $6 \mathrm{c}$ depicts regressions that

TABLE 1. NODE ACCUMULATION, LEAF AREA PER NODE, LEAF AREA PER CANE, AND LEAF AREA INDEX FOR RUBUS URSINUS AT SACRAMENTO AND $R$. PROCERUS AT ALBANY DURING THE FALL 1979 AND SPRING-SUMMER 1980

\begin{tabular}{|c|c|c|c|c|c|c|c|c|c|}
\hline Species & Date & $\mathbf{N}$ & $\begin{array}{c}\text { Mean } \\
\text { nodes } \\
\text { per } \\
\text { cane }\end{array}$ & $\mathrm{SD}(\mathrm{CV})$ & $\begin{array}{c}\text { Mean leaf } \\
\text { area } \\
\left(\mathrm{cm}^{2}\right) \\
\text { per node }\end{array}$ & $\mathrm{SD}(\mathrm{CV})$ & $\begin{array}{c}\text { Mean leaf } \\
\text { area } \\
\left(\mathrm{cm}^{2}\right) \\
\text { per cane }\end{array}$ & $\mathrm{SD}(\mathrm{CV})$ & $\begin{array}{c}\text { Leaf } \\
\text { area } \\
\text { index }\end{array}$ \\
\hline Rubus & Aug. 1-Aug. 22 & 19 & 5.26 & $2.45(46.9)$ & - & - & - & - & - \\
\hline \multirow[t]{3}{*}{ ursinus } & Aug. 22-Sept. 4 & 21 & 2.33 & $1.85(79.4)$ & - & - & - & - & - \\
\hline & Apr. 14-May 4 & 30 & 8.07 & $1.72(21.3)$ & 29.8 & $3.86(13.0)$ & 239.7 & $57.44(24.0)$ & 6.79 \\
\hline & May 5-May 25 & 29 & 7.83 & $2.17(27.7)$ & 25.3 & $7.42(29.3)$ & 198.6 & $87.35(44.0)$ & 7.92 \\
\hline Rubus & Sept. 18-Oct. 15 & 6 & 7.67 & $4.46(58.1)$ & 54.3 & $7.39(13.6)$ & 438.9 & $331.6 \quad(75.6)$ & - \\
\hline \multirow{2}{*}{ procerus } & June 3-July 2 & 13 & 8.62 & $2.47(28.7)$ & 52.7 & $17.2(32.6)$ & 486.2 & $316.9 \quad(65.2)$ & 5.84 \\
\hline & July 4-Aug. 1 & 22 & 7.91 & $2.56(32.4)$ & 39.9 & 16.7 (41.9) & 341.5 & $222.4 \quad(65.1)$ & - \\
\hline
\end{tabular}


include (solid line) and exclude (dashed line) outlying data on one rapidly growing primocane (thin line at top). Rubus ursinus was more determinate, as all canes stopped growing at about the same time, while $R$. procerus produced some rapidly growing primocanes throughout the season, as seen in figure $6 \mathrm{c}$.

\section{Cane Densities}

Mean quadrat counts ( 1 quadrat $=0.25 \mathrm{~m}^{2}$ ) are given for $R$. ursinus in table 2 . The majority of emerging shoots were primocanes, as inflorescence-bearing shoots in samples never exceeded 3.4 percent. The numbers of canes decreased steadily through the season as faster growing canes shaded out slower growing ones.

Table 3 gives mean numbers of vertical shoots per quadrat for $R$. procerus at Albany. Most of the shoots in the quadrats were floral laterals and most actually originated from only one to three floricanes. Means (not given elsewhere) and 95 percent confidence intervals for the 20 floral laterals examined were $9.9 \pm 0.8$ nodes per shoot; $451.7 \pm 93.3$ $\mathrm{cm}^{2}$ leaf area per shoot, and $44.2 \pm 7.2 \mathrm{~cm}^{2}$ per leaf.
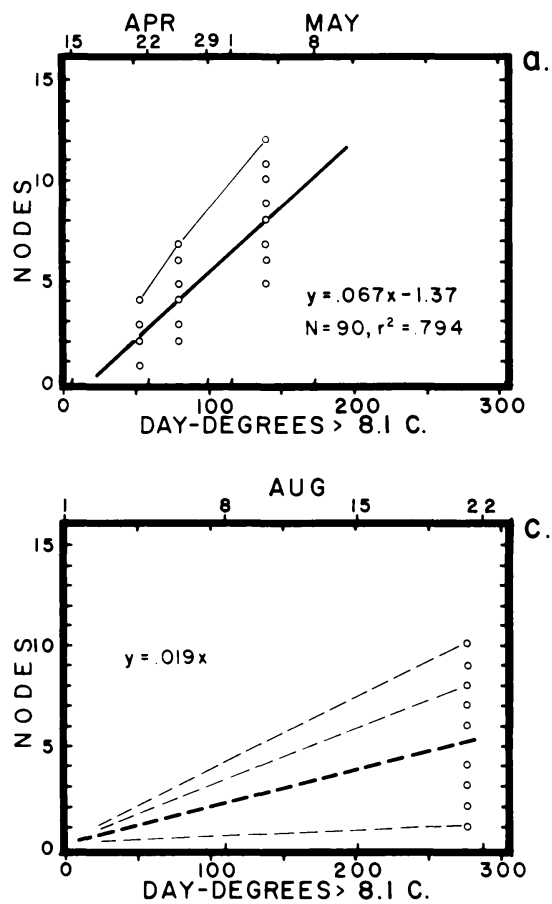

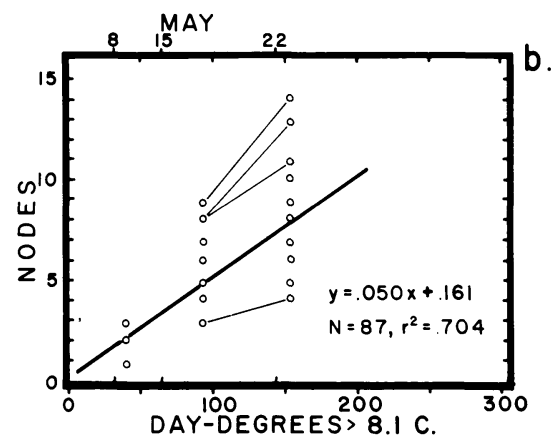

\section{SACRAMENTO RUBUS URSINUS}

SINGLE CANES - -

Fig. 5. Mean node accumulation for Rubus ursinus canes at Sacramento as a function of physiological time $\left({ }^{\circ} \mathrm{D}>8.12^{\circ} \mathrm{C}\right)$ for three growing periods in 1979-80. Fig. 5a. April 14-May 4, 1980; 30 canes. Fig. 5b. May 5-25, 1980; 29 canes. Fig. 5c. August 1-21, 1979; 19 canes. Heavy solid lines represent linear regressions; thin lines, accumulations for single, outlying canes. In fig. 5c, nodes were counted at the end of the observation period only, and thick and thin dashed lines are drawn from the origin through the mean and outliers, respectively, for purposes of comparison with fig. 6c. 
TABLE 2. DENSITIES OF SHOOTS (SHOOTS PER $0.25 \mathrm{M}^{2}$ ) IN RUBUS URSINUS AND PERCENTAGES OF FLORAL SHOOTS AT SACRAMENTO SITE, SPRING 1980

\begin{tabular}{lccccc}
\hline \hline $\begin{array}{l}\text { Sample } \\
\text { date }\end{array}$ & N & $\begin{array}{c}\text { Mean } \\
\text { density }\end{array}$ & SD & $\begin{array}{c}\text { Mean \% floral } \\
\text { shoots per quadrat }\end{array}$ & SD \\
\hline Apr. 14 & 30 & 20.1 & 8.30 & 0.0 & 0.0 \\
Apr. 21 & 30 & 17.9 & 4.13 & 2.0 & 5.34 \\
Apr. 28 & 29 & 17.5 & 3.37 & 3.4 & 7.03 \\
May 5 & 30 & 16.8 & 3.28 & 2.5 & 4.88 \\
May 12 & 30 & 11.3 & 2.41 & 1.5 & 3.37 \\
\hline
\end{tabular}

TABLE 3. DENSITIES OF SHOOTS (SHOOTS PER $0.25 \mathrm{M}^{2}$ ) IN RUBUS PROCERUS AND PERCENTAGES OF FLORAL SHOOTS AT ALBANY SITE, SPRING 1980

\begin{tabular}{lccccc}
\hline \hline $\begin{array}{l}\text { Sample } \\
\text { date }\end{array}$ & $\mathbf{N}$ & $\begin{array}{c}\text { Mean } \\
\text { density }\end{array}$ & SD & $\begin{array}{c}\text { Mean \% floral } \\
\text { shoots per quadrat }\end{array}$ & SD \\
\hline May 8 & 15 & 11.2 & 3.00 & 99.5 & 1.99 \\
May 8 & 15 & 11.5 & 2.23 & 83.4 & 22.6 \\
May 19 & 15 & 10.0 & 2.42 & 93.4 & 11.6 \\
May 28 & 15 & 9.67 & 1.23 & 96.8 & 7.23 \\
May 31 & 15 & 8.60 & 1.68 & 80.0 & 25.3 \\
\hline
\end{tabular}
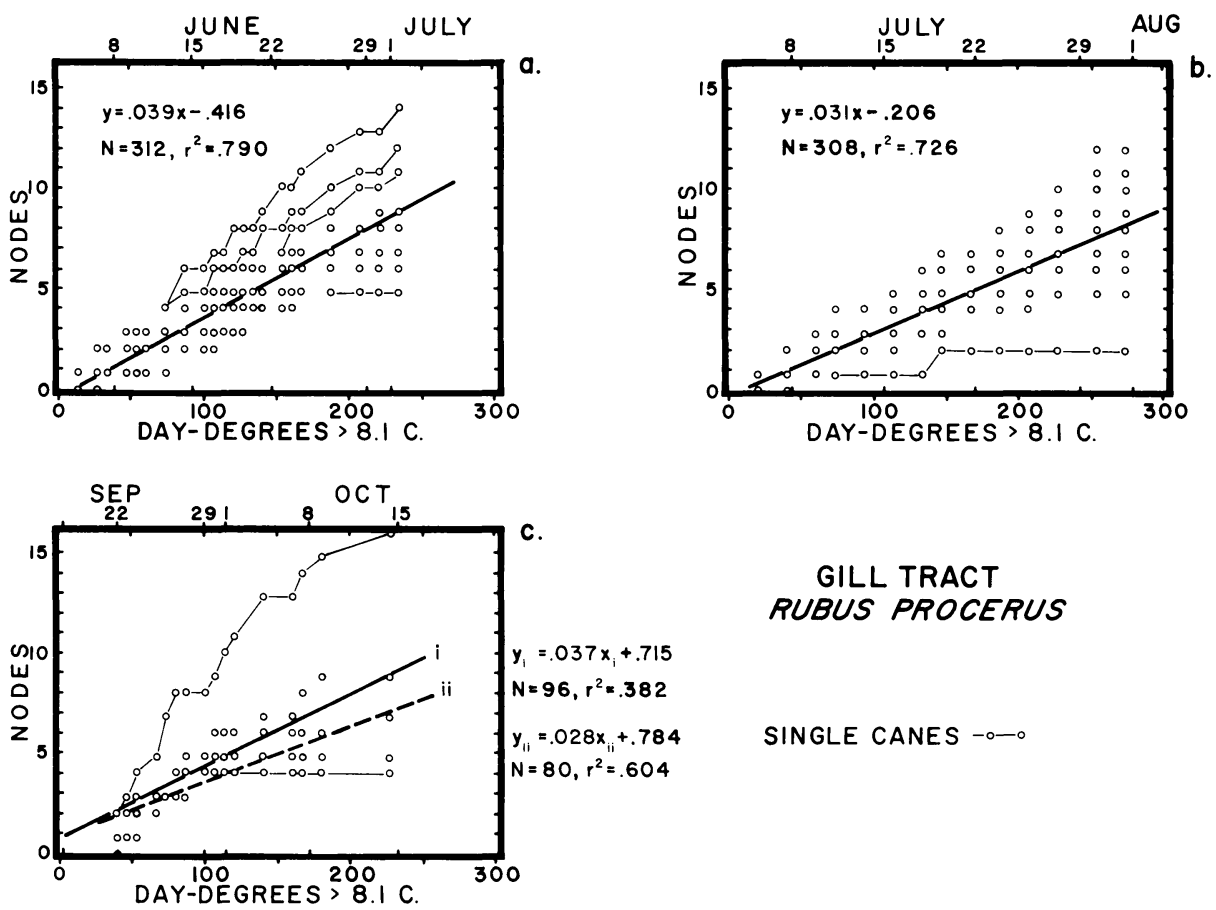

\section{GILL TRACT RUBUS PROCERUS}

SINGLE CANES -०-०

Fig. 6. Mean node accumulation for Rubus procerus at Gill Tract as a function of physiological time $\left({ }^{\circ} \mathrm{D}>8.12^{\circ} \mathrm{C}\right)$ for three growing periods in 1979-80. Fig. 6a. June 3-July 2, 1980; 13 canes. Fig. 6b. July 4-August 1, 1980; 22 canes. Fig. 6c. September 18-October 15, 1979; 6 canes. Heavy solid lines represent linear regressions; thin lines, accumulations for single outlying canes. In fig. $6 \mathrm{c}$, the dashed line (ii) represents the linear regression when the fast-growing outlier (top of graph) is deleted. 


\section{Leaf Area Indices}

Leaf Area Index (LAI) for a plant canopy is the amount of leaf surface area directly over a unit area of soil surface. Because of the dense and thorny canopy of interwoven canes in blackberry brambles, LAIs are difficult to measure. Leaf Area Index estimates for $R$. ursinus during the two early season periods and for $R$. procerus during the second summer period are given in table 1.

The LAIs for Rubus ursinus were computed simply as the numbers of primocanes per $\mathrm{m}^{2}(\mathrm{D})$ multiplied by the mean leaf area (in $\mathrm{m}^{2}$ ) per cane (A)

$$
\mathrm{LAI}=\mathrm{D} \cdot \mathrm{A} \text {. }
$$

The computation for $R$. procerus was different than that for the native blackberry because the bramble at Albany consisted of a mixture of primocanes and floricanes. Leaf Area Index was estimated as

$$
L A I=D \cdot\left(p \cdot A_{1}+(1-p) \cdot A_{2}\right)
$$

where

$A_{1}=$ mean leaf area $\left(\mathrm{m}^{2}\right)$ per floral shoot,

$A_{2}=$ mean leaf area $\left(\mathrm{m}^{2}\right)$ accumulated per primocane in observation period,

$\mathrm{D}=$ average number of canes per $\left(\mathrm{m}^{2}\right)$ at end of period, and

$\mathrm{p}=$ mean proportion of floral shoots in quadrat.

The low LAI of $R$. procerus (5.84) reflects the preponderance of determinate floral shoots, while the higher values for $R$. ursinus reflect the predominance of primocane growth.

\section{Phenology of the Blackberry Leafhopper}

\section{Population Dynamics}

Figures 7, 8, and 9 show BLH population trends for the Sacramento, Oakville, and Strawberry Canyon sites for the years 1978 to 1980 . The data are plotted on a physiological time scale $\left({ }^{\circ} \mathrm{D}>8.12^{\circ} \mathrm{C}\right.$ ) for the calendar years of the study. Length in ${ }^{\circ} \mathrm{D}$ of the 1978 calendar year at Oakville was 2863; those of the 1979 year were 2873 at Oakville, 2615 at Sacramento, and 2477 at Strawberry Canyon. Vertical bars at points on the egg and nymph curves represent 95 percent confidence intervals about means (per $30 \mathrm{~cm}^{2}$ of leaf, or one "unit" leaf). The confidence intervals are rather broad; note especially those for the nymphs at Sacramento. These broad limits are indicative of low density populations that are clumped in their distribution. Indeed, population densities rarely exceeded 0.5 insects per unit leaf at any of the sites. Greater precision was not possible, since the 120-leaf samples were the largest that could be processed given the time constraints of the study. Points on adult curves are average catches per trap for three sticky traps at Oakville and four traps each at Sacramento and Strawberry Canyon.

In 1979 immature densities were highest at Sacramento where they rose steadily throughout the season until oviposition ceased at about $1945^{\circ} \mathrm{D}$. Although they were high in the latter half of 1978, densities at Oakville maintained a steady low level in 1979, with only a small peak in the second generation. At Strawberry Canyon in 1979, populations were so sparse that immatures were only sporadically observed. The sums of the total areas under the egg and nymph curves (see the life table section) divided by the immature mean developmental time $\left(608^{\circ} \mathrm{D}\right)$ provide a means of comparing the relative population 


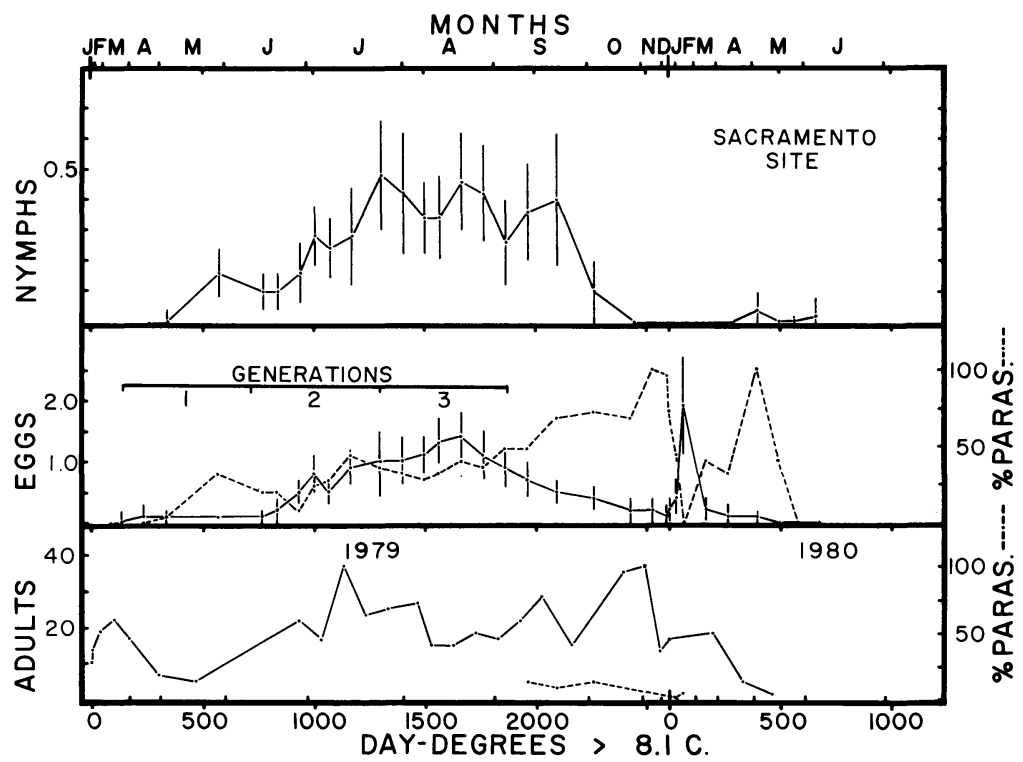

Fig. 7. Blackberry leafhopper phenology at the Sacramento site in 1979-80. The abscissa is scaled in physiological time $\left({ }^{\circ} \mathrm{D}>8.12^{\circ} \mathrm{C}\right)$ below the axis and calendar time above. Top, nymphal abundance in nymphs per $30 \mathrm{~cm}^{2}$ leaf. The vertical bars are $95 \%$ confidence intervals about the means of the 120 -leaf samples. Middle, total egg abundance in eggs per $30 \mathrm{~cm}^{2}$ leaf. The vertical bars are $95 \%$ confidence intervals about the means of the 120-leaf samples. The dotted line connects the percentages of parasitization by Anagrus epos. Bottom, mean numbers of adults per sticky traps (four traps in all). The dotted line connects percentages of adult parasitization by pipunculids and dryinids during the 1979-80 overwintering period.

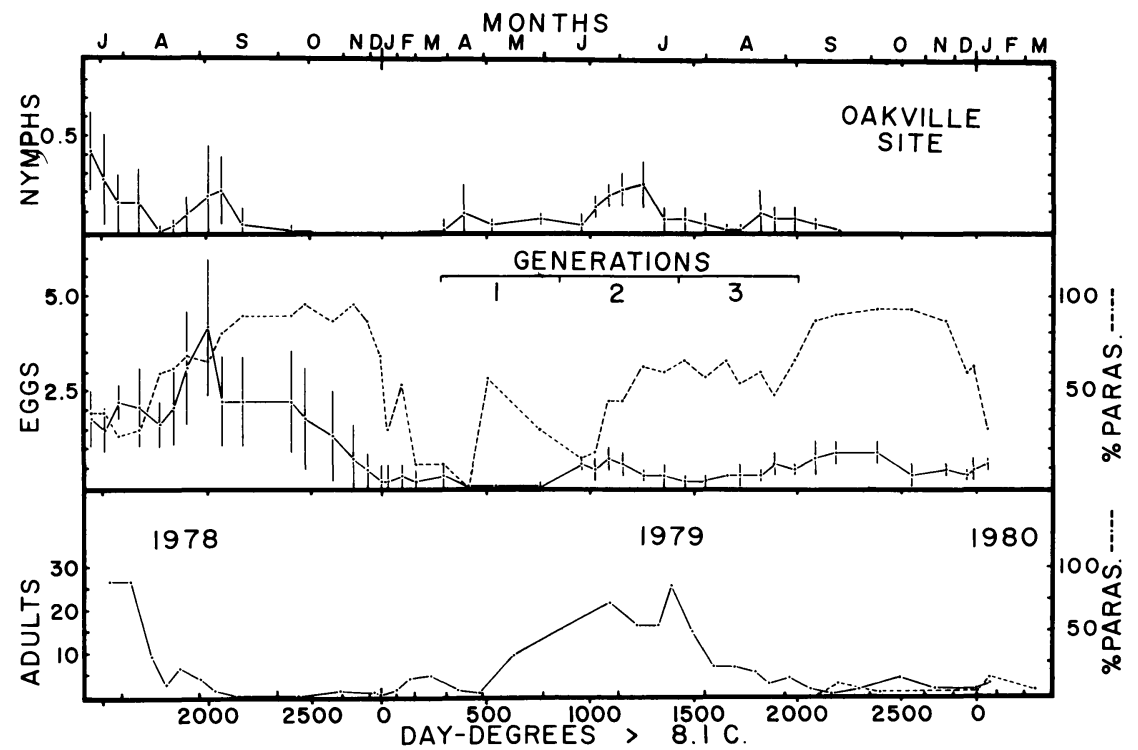

Fig. 8. Blackberry leafhopper phenology at the Oakville site in 1978-80. The abscissa is scaled in physiological time $\left({ }^{\circ} \mathrm{D}>8.12^{\circ} \mathrm{C}\right)$ below the axis and calendar time above. Top, nymphal abundance in nymphs per $30 \mathrm{~cm}^{2}$ leaf. The vertical bars are $95 \%$ confidence intervals about the 120-leaf means. Middle, total egg abundance in eggs per $30 \mathrm{~cm}^{2}$ leaf. Vertical bars are $95 \%$ confidence intervals about the means of the 20-leaf samples for 1978 and the means of the 120-leaf samples for 1979-80. The dotted line connects percentages of parasitization by Anagrus epos. Bottom, mean numbers of adults per sticky trap (three sticky traps in all). The dotted line connects percentages of parasitization by pipunculids and dryinids during the $1979-80$ overwintering period. 
sizes at the three sites in 1979. Seasonal mean densities were 3.16 (Sacramento), 2.17 (Oakville), and 0.05 (Strawberry Canyon) insects per $30 \mathrm{~cm}^{2}$ unit leaf. Hence the seasonal population density at Sacramento was about 1.5 times that at Oakville and over 60 times larger than that at Strawberry Canyon.

\section{Adult Diapause in the Blackberry Leafhopper}

Tables $4 \mathrm{a}, 4 \mathrm{~b}$, and $4 \mathrm{c}$ present percentages of diapause, intermediate (that is, with immature eggs in ovarioles), and gravid BLH at four locations for the winters of 1978-79 and 1979-80. These data points are represented as open circles or large dots in figures 9, 10, and 11 , while the estimated termination and induction curves are represented as long-dashed lines. Termination curves were approximated at each site by lumping data points for the 2 years and fitting them with linear regressions. Dissections inadvertantly were begun in 1979 after the onset of diapause, so the induction curves are approximated arbitrarily as mirror images of the termination curves with their upper tails terminating at the points where 100 percent diapause was first observed. Both the induction and termination phases take place over very short periods of time and the winter sampling interval of 2 to 3 weeks was too long to measure either process accurately.

Diapause in Homoptera is influenced by both photoperiod and host plant quality, and can be modified by temperature. The first two factors are shown together with the Sacramento

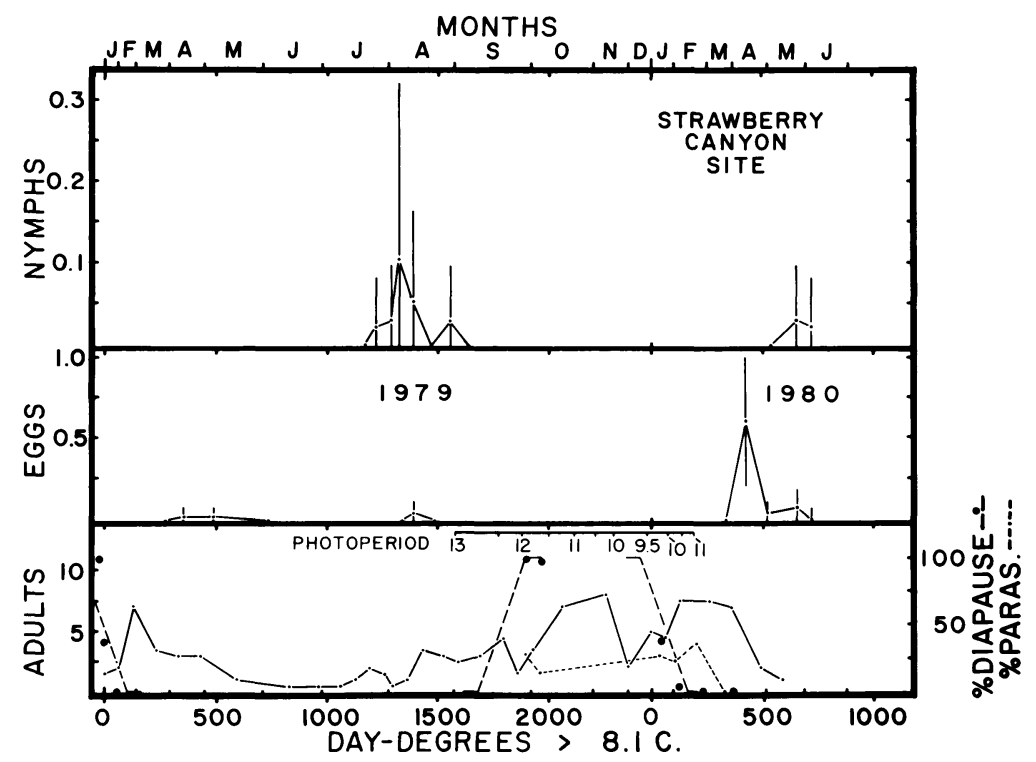

Fig. 9. Blackberry leafhopper phenology at the Strawberry Canyon site in 1979-80. The abscissa is scaled in physiological time $\left({ }^{\circ} \mathrm{D}>8.12^{\circ} \mathrm{C}\right)$ below the axis and calendar time above. Top, nymphal abundance in nymphs per $30 \mathrm{~cm}^{2}$ leaf. The vertical bars are $95 \%$ confidence intervals about the means of the 30- or 60-leaf samples. Middle, total egg abundance in eggs per $30 \mathrm{~cm}^{2}$ leaf. The vertical bars are $95 \%$ confidence intervals about the means of the 30 - or 60 -leaf samples. Note that Anagrus epos parasitization was not found here, due in part to the low BLH egg densities. Bottom, mean numbers of adults per sticky trap (four traps in all). Large dots are percentages of females in diapause; dashed lines, diapause induction and termination curves. Photoperiod (hours of daylight) is shown above the diapause curves. The dotted line connects percentages of adult parasitization by pipunculids and dryinids during the $1979-80$ overwintering period. 
TABLE 4A. PERCENTAGE OF BLH FEMALES IN DIAPAUSE, INTERMEDIATE, AND GRAVID STATES AT THE SACRAMENTO SITE IN THE WINTERS OF 1978-79 AND 1979-80

\begin{tabular}{llcccc}
\hline \hline Phase & \multicolumn{1}{c}{ Date } & $\mathbf{N}$ & \% Diapause & \% Intermediate & \% Gravid \\
\hline Induction & Sept. 12, 1979 & 13 & 100.0 & 0.0 & 0.0 \\
& Sept. 19, 1979 & 29 & 96.2 & 3.8 & 0.0 \\
& Oct. 5, 1979 & 28 & 100.0 & 0.0 & 0.0 \\
& Oct. 27, 1978 & 5 & 100.0 & 0.0 & 0.0 \\
Termination & Nov. 10, 1978 & 6 & 83.3 & 0.0 & 16.7 \\
& Jan. 6, 1979 & 29 & 96.6 & 0.0 & 3.4 \\
& Jan. 11, 1980 & 40 & 46.2 & 46.2 & 7.6 \\
& Feb. 22, 1979 & 31 & 35.5 & 64.5 & 0.0 \\
& Feb. 1, 1980 & 36 & 28.6 & 31.4 & 40.0 \\
& Feb. 14, 1979 & 26 & 0.0 & 48.0 & 52.0 \\
& Feb. 22, 1980 & 27 & 12.0 & 40.0 & 48.0 \\
\hline
\end{tabular}

TABLE 4B. PERCENTAGE OF BLH FEMALES IN DIAPAUSE, INTERMEDIATE, AND GRAVID STATES IN THE NAPA VALLEY IN THE WINTERS OF 1978-79 AND 1979-80

\begin{tabular}{lllrrrr}
\hline \hline Phase & \multicolumn{1}{c}{ Date } & Location & N & $\begin{array}{c}\text { \% } \\
\text { Diapause }\end{array}$ & $\begin{array}{r}\text { \% Inter- } \\
\text { mediate }\end{array}$ & $\begin{array}{r}\text { \% } \\
\text { Gravid }\end{array}$ \\
\hline Induction & Sept. 12, 1979 & Oakville & 13 & 69.2 & 30.8 & 0.0 \\
& Sept. 19, 1979 & Oakville & 22 & 55.0 & 25.0 & 20.0 \\
& Oct. 5, 1979 & Oakville & 29 & 96.4 & 3.6 & 0.0 \\
& Oct. 13, 1978 & St. Helena & 11 & 9.1 & 90.9 & 0.0 \\
& Oct. 27, 1978 & St. Helena & 9 & 100.0 & 0.0 & 0.0 \\
Termination & Nov. 10, 1978 & St. Helena & 15 & 100.0 & 0.0 & 0.0 \\
& Dec. 29, 1978 & Oakville & 9 & 55.6 & 11.1 & 33.3 \\
& Jan. 3, 1979 & Oakville & 12 & 25.0 & 58.3 & 16.7 \\
& Jan. 3, 1979 & St. Helena & 22 & 86.4 & 13.6 & 0.0 \\
& Jan. 11, 1980 & Oakville & 24 & 17.4 & 21.7 & 60.7 \\
& Jan. 22, 1979 & Oakville & 35 & 0.0 & 14.3 & 85.7 \\
& Feb. 1, 1980 & Oakville & 29 & 4.0 & 16.0 & 80.0 \\
& Feb. 14, 1979 & Oakville & 21 & 0.0 & 0.0 & 100.0 \\
& Feb. 22, 1980 & Oakville & 16 & 7.1 & 14.3 & 78.6 \\
& Mar. 24, 1980 & Oakville & 14 & 0.0 & 0.0 & 100.0 \\
\hline
\end{tabular}

TABLE 4C. PERCENTAGE OF BLH FEMALES IN DIAPAUSE, INTERMEDIATE, AND GRAVID STATES IN ALBANY IN THE WINTERS OF 1978-79 AND 1979-80

\begin{tabular}{llcccc}
\hline \hline Phase & Date & N & \% Diapause & \% Intermediate & \% Gravid \\
\hline Induction & Sept. 29, 1979 & 18 & 100.0 & 0.0 & 0.0 \\
& Oct. 6, 1979 & 26 & 95.5 & 4.5 & 0.0 \\
\multirow{5}{*}{ Termination } & Oct. 28, 1978 & 10 & 100.0 & 0.0 & 0.0 \\
& Jan. 4, 1979 & 13 & 100.0 & 0.0 & 0.0 \\
& Jan. 13, 1980 & 26 & 39.0 & 55.6 & 5.4 \\
& Jan. 23, 1979 & 19 & 26.7 & 73.3 & 0.0 \\
& Feb. 2, 1980 & 22 & 6.0 & 70.5 & 23.5 \\
& Feb. 16, 1980 & 30 & 3.6 & 39.8 & 57.6 \\
& Feb. 22, 1980 & 20 & 0.0 & 0.0 & 100.0 \\
& Mar. 26, 1980 & 17 & 0.0 & 0.0 & 100.0 \\
\hline
\end{tabular}




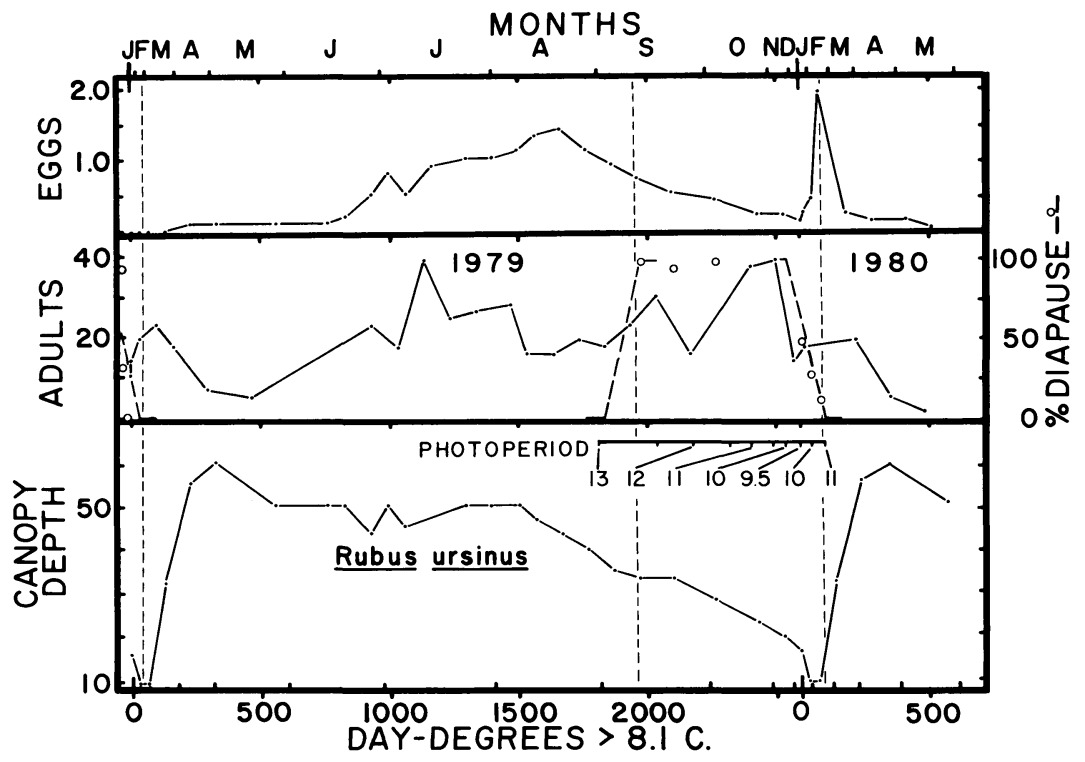

Fig. 10. Synchronization of blackberry leafhopper diapause and Rubus ursinus phenology at Sacramento in 1979-80. The dashed vertical lines mark the end points of diapause induction and termination. The induction phase (center dashed line) ends at about 12.75 hours photoperiod (early September) at the midpoint of canopy decline. The termination phase ends at about 10.5 hours photoperiod (outer dashed lines) and oviposition coincides with the flush of blackberry cane growth in early spring.

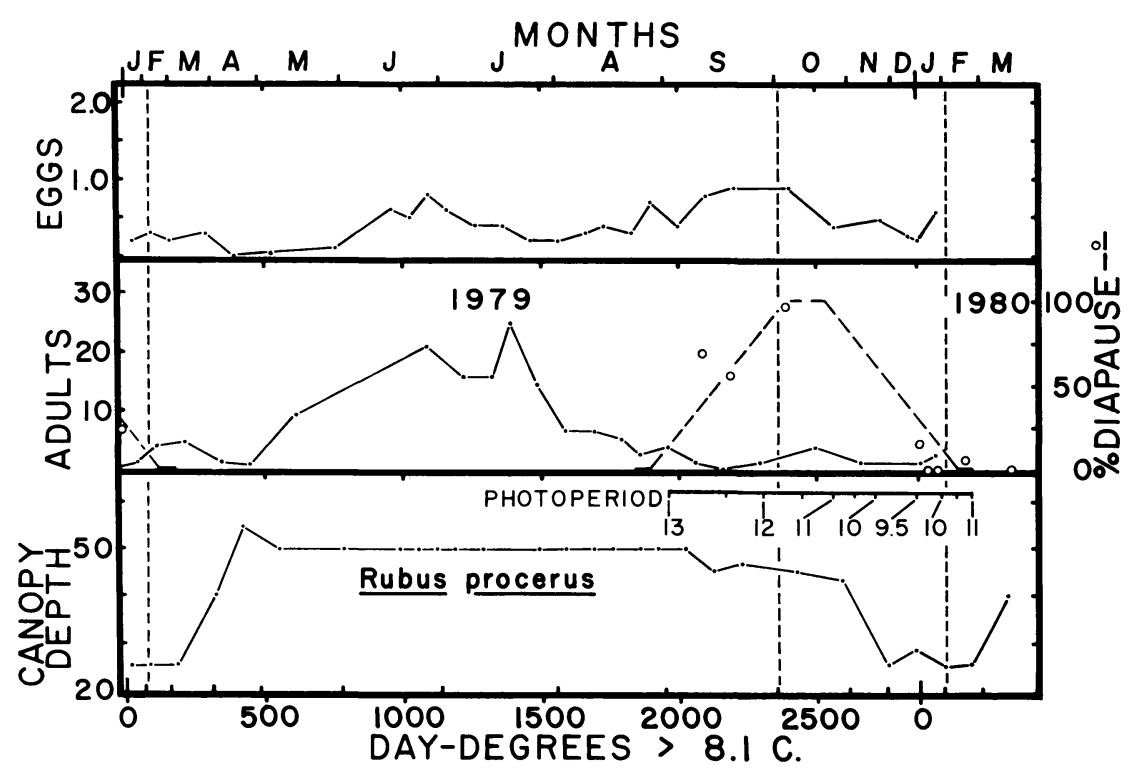

Fig. 11. Synchronization of blackberry leafhopper diapause and Rubus procerus phenology at Oakville in 1979-80. The dashed vertical lines mark the end points of diapause induction and termination. The induction phase (center dashed line) ends at about 11.75 hours photoperiod (late September) during canopy decline. The termination phase ends by 10.5 hours photoperiod (outer dashed lines), but the growth spurt of the blackberry canes occurs later in spring than in $R$. Ursinus, and oviposition is delayed by several weeks. 
and Oakville diapause curves in figures 10 and 11 . The dotted vertical lines show the relationships between the end points of diapause induction and termination, increases in observed oviposition patterns, and canopy growth and senescence (which serves as a crude index of host plant physiological state). Diapause induction and termination curves for BLH, and photoperiod are shown for Strawberry Canyon in figure 9. The median critical photoperiod for induction in all cases lies between 13.5 and 13.75 hours, which occurs between the second and third weeks of September. Termination seems to begin just after the winter solstice (December 21), as daylength increases from 9.5 hours. Blackberry leafhopper reproductive activity is correlated with the physiological state of the native blackberry (fig. 10); diapause induction occurs as the canopy is shrinking, while diapause termination takes place just before the cane growth begins in spring, so that oviposition coincides with the presence of new leaves. Apparently, similar photoperiod triggers are used by both BLH and its host. This close synchrony of leafhopper and host plant phenologies differs sharply from that observed for BLH on the imported blackberry (fig. 11), where diapause induction correlates with the decline in canopy height, but diapause termination and adult activity occur appreciably before the new plant growth is available. This lag period delays oviposition and may reduce BLH adult survival. Because $R$. procerus has been imported into California only recently, it appears that BLH has not adapted completely to its phenology.

\section{Parasitization}

Percentages of parasitization of the egg stage by Anagrus are shown in figures 7 and 8 (previously discussed). At both Sacramento and Oakville, low percentages of parasitization were observed in the first (spring) generation of eggs, but parasitization increased steadily throughout the season to nearly 95 percent when BLH oviposition ceased. Anagrus apparently overwinters in an immature diapause state in late season BLH eggs. Parasitized eggs were not encountered at Strawberry Canyon because of generally low egg densities.

Percentages of parasitization of BLH adults by pipunculids and dryinids are listed in table 5 and are shown in the lower graphs of figures 7, 8, and 9. These data are for the

TABLE 5. PARASITIZATION PERCENTAGES OF OVERWINTERING BLH ADULTS BY PIPUNCULIDS AND DRYINIDS AT THREE NORTHERN CALIFORNIA LOCATIONS IN 1979-1980

\begin{tabular}{lccccccccc}
\hline \hline & \multicolumn{3}{c}{ Sacramento } & \multicolumn{3}{c}{ Oakville } & \multicolumn{3}{c}{ Albany } \\
\cline { 2 - 10 } Date & $\mathbf{N}$ & \% Pips & \% Drys & N & \% Pips & \% Drys & N & \% Pips & \% Drys \\
\hline Sept. 12 & 13 & 15.4 & 0.0 & 13 & 0.0 & 0.0 & - & - & - \\
Sept. 19 & 29 & 10.4 & 0.0 & 22 & 9.1 & 0.0 & - & - & - \\
Sept. 29 & - & - & - & - & - & - & 18 & 27.8 & 0.0 \\
Oct. 5 & 28 & 17.9 & 0.0 & 29 & 3.5 & 0.0 & - & - & - \\
Oct. 6 & - & - & - & - & - & - & 26 & 15.4 & 0.0 \\
Jan. 11 & 40 & 2.5 & 0.0 & 24 & 4.2 & 0.0 & - & - & - \\
Jan. 13 & - & - & - & - & - & - & 26 & 30.8 & 0.0 \\
Feb. 1 & 36 & 2.7 & 0.0 & 29 & 6.9 & 6.9 & - & - & - \\
Feb. 2 & - & - & - & - & - & - & 22 & 22.7 & 0.0 \\
Feb. 22 & 27 & 7.5 & 0.0 & 16 & 6.25 & 6.25 & 20 & 25.0 & 15.0 \\
Mar. 24 & - & - & - & 14 & 0.0 & 0.0 & - & - & - \\
Mar. 26 & - & - & - & - & - & - & 17 & 0.0 & 0.0 \\
\hline
\end{tabular}


winter only, when diapause adults were collected for dissection. Since the parasite larvae could not be identified and attempts at rearing the adult parasites were unsuccessful, the pipunculids and dryinids could not be identified to species. The dryinids were likely of the genus Aphelopus, since a species of this genus ( $A$. comesi Fenton) is known to attack the grape leafhopper (Cate, 1975). Parasitization was highest at Albany, where it reached 40 percent at one date, and did not exceed 18 percent at Sacramento and 14 percent at Oakville. Most parasitization was by pipunculids at all sites. Pipunculid parasitization is not evident externally and was discovered fortuitously during dissections of diapausing BLH adults. Since parasitization data were collected only during the overwintering period, nothing can be said concerning the seasonal dynamics of pipunculids and dryinids.

\section{Life Table Analysis of Blackberry Leafhopper Populations in the Field}

\section{Field Survivorship}

Blackberry leafhopper immature stage survival rates were calculated by the method of Kiritani and Nakasuji (1967), as modified by Manly (1976, 1977). Strictly applied, the method requires populations with discrete generations, hence parameters calculated when generations overlapped must be regarded with reservation. The method assumes a constant daily (or per ${ }^{\circ} \mathrm{D}$ ) survival rate for each stage within a generation.

Stage-specific survival rates for the blackberry leafhopper during 1979 at the Sacramento and Oakville sites are presented in tables 6 and 7. Survival rates for the first and second, and third and fourth instars were calculated by lumping population counts for the pairs, because the instars within each could not be distinguished readily from each other. Computed survival values larger than one were set to 1.0. Such values resulted from small sample sizes.

At Sacramento, total immature survival decreased steadily through successive generations: 0.096 in the first, 0.071 in the second, and 0.007 in the third. Egg mortality in BLH was due primarily to parasitism by $A$. epos, while nymphal mortality accrued from predation and parasitization. Egg survival was relatively high $(0.834,0.627$, and 0.488 in

TABLE 6. BLH STAGE-SPECIFIC SURVIVALS FOR THREE GENERATIONS AND THE ENTIRE YEAR AT THE SACRAMENTO SITE IN 1979. SURVIVALS CALCULATED BY THE METHOD OF KIRITANI AND NAKASUJI (1967), AS MODIFIED BY MANLY $(1976,1977)$

\begin{tabular}{lcccc}
\hline \hline Stage & Generation 1 & Generation 2 & Generation 3 & Entire year \\
\hline Egg & 0.8335 & 0.6271 & 0.4875 & 0.5599 \\
Instars I-II* & 0.4077 & 0.4735 & 0.5346 & 0.4996 \\
Instars III-IV* & 0.8315 & 0.7137 & 0.5137 & 0.6168 \\
Instar V & $1.0(5.183 \dagger)$ & 0.9955 & 0.1838 & $1.0(1.140 \dagger)$ \\
\hline \multicolumn{1}{c}{ Total nymphs } & 0.1149 & 0.1137 & 0.0139 & 0.0950 \\
\multicolumn{1}{c}{ Total immatures } & 0.0960 & 0.0713 & 0.0068 & 0.0532 \\
\hline Egg \% parasitization & 16.7 & 35.3 & 46.5 & 40.5 \\
\hline
\end{tabular}

*Densities upon which survivals are based were averaged for instars I-II and III-IV, as these stages could not be distinguished readily in the field. Values represent survival per instar.

+Value set to 1.0 because sampling error due to low population density gave unrealistic survival estimate. 
the successive generations), while total nymphal survival was low $(0.115,0.114$, and $0.014)$, respectively).

The pattern of total immature survival at Oakville was similar to that observed at Sacramento: first-, second-, and third-generation survival rates were $0.083,0.037$, and 0.008 , respectively. The components of survival shifted in importance, however, with egg survival becoming dominant, especially in the last generation. Egg survival rates were $0.684,0.540$, and 0.132 in the first through third generations, respectively, while total nymph survivals were $0.122,0.069$, and 0.059 . The high Anagrus mortality in the third generation resulted from the geometric increase in parasite numbers (probably emerging from GLH eggs in the nearby vineyards) late in the season (see fig. 8).

Figure 12 illustrates the dependence of survival rates of eggs and total nymphs for the two sites on within-generation densities calculated from life table analyses. The egg survivorships from both sites and the nymphal survivorships from the Sacramento site show strong negative linear density dependence. The data points on the three curves, from left to right, are the survivorships for the first, second, and third generations. Only one data point, estimated from low nymphal populations at Oakville, does not follow the general trend. This point represents a third-generation result and, while departing significantly from general trends, is still reasonable. The low nymphal population was due to low egg survival during the generation (see table 7 ).

\section{Mortality Factors}

Besides the egg and nymphal-adult parasites already discussed, a number of general predators at the three sites contributed to BLH mortality, but only qualitative observations on their impact are available. Spiders were very abundant in the rich riparian habitats: among them were agelenid species, whose sheet webs covered 5 to 10 percent of the upper canopy of blackberry during the late summer, and thomisids and salticids, found on and under blackberry leaves throughout the summer. The large red mite, Anystis agilis (Banks), was observed frequently at Oakville, although it was not found at the other sites.

Nymphs and adults of Paraproba pendula Van Duzee (Hemiptera : Miridae) were abundant at the Strawberry Canyon site in 1979 and probably contributed to the depression of BLH

TABLE 7. BLH STAGE-SPECIFIC SURVIVALS FOR THREE GENERATIONS AND THE ENTIRE YEAR AT THE OAKVILLE SITE IN 1979. SURVIVALS CALCULATED BY THE METHOD OF KIRITANI AND NAKASUJI (1967), AS MODIFIED BY MANLY (1976, 1977)

\begin{tabular}{lcccc}
\hline \hline Stage & Generation 1 & Generation 2 & Generation 3 & Entire year \\
\hline Egg & 0.6842 & 0.5398 & 0.1318 & 0.2964 \\
Instars I-II* & 0.3666 & 0.3271 & 0.3195 & 0.3325 \\
Instars III-IV* & 0.9507 & $1.0(1.065 \dagger)$ & 0.7599 & 0.9700 \\
Instar V & $1.0(1.604 \dagger)$ & 0.6457 & $1.0(1.207 \dagger)$ & 0.9355 \\
\hline \multicolumn{1}{c}{ Total nymphs } & 0.1215 & 0.0691 & 0.0589 & 0.0973 \\
Total immatures & 0.0831 & 0.0373 & 0.0078 & 0.0288 \\
\hline Egg \% parasitization & 25.7 & 44.1 & 84.1 & 67.6 \\
\hline
\end{tabular}

*Densities upon which survivals are based were averaged for instars I-II and III-IV, as these stages could not be distinguished readily in the field. Values represent survival per instar.

†Value set to 1.0 because sampling error due to low population density gave unrealistic survival estimate. 
populations during the period $720-2060^{\circ} \mathrm{D}$. Total mirid density (nymphs + adults) reached levels of 0.5 to 1.0 bugs per blackberry leaf during late summer and was equally high on other plant species at the site. Adult numbers caught on the four sticky traps were as high as 100 at the population peak in early September. In a small experiment in which $10 \mathrm{BLH}$ nymphs were caged with three mirid adults, the mirids killed and consumed all nymphs in the course of a day.

\section{Oviposition and Percent Parasitization in the Blackberry Canopy Strata}

Figures 13 and 14 show (a) the proportions of the total BLH oviposition and (b) the total percentage of Anagrus parasitization observed in each of the four canopy levels sampled at the Sacramento and Oakville sites during 1979. Time in the plots is in ${ }^{\circ} \mathrm{D}$ above $8.12^{\circ} \mathrm{C}$. The data points for each factor over time in each stratum were connected with straight line segments. On a given date, the length of a vertical line segment within a shaded area (a stratum) represents (a) the proportion of eggs and (b) percent parasitization found within that stratum. For example, in figure 13a, on the first sample date, the proportions of all eggs found in levels I (lowest), II, III, and IV (highest) were about 0.35, $0.15,0.28$, and 0.22 , respectively. Regression lines computed through each set of points separating the four strata sampled are superimposed on the figures.

None of the regression slopes for BLH oviposition in $R$. ursinus at Sacramento (fig. $13 a)$ is significantly different from zero, hence BLH oviposition patterns were constant

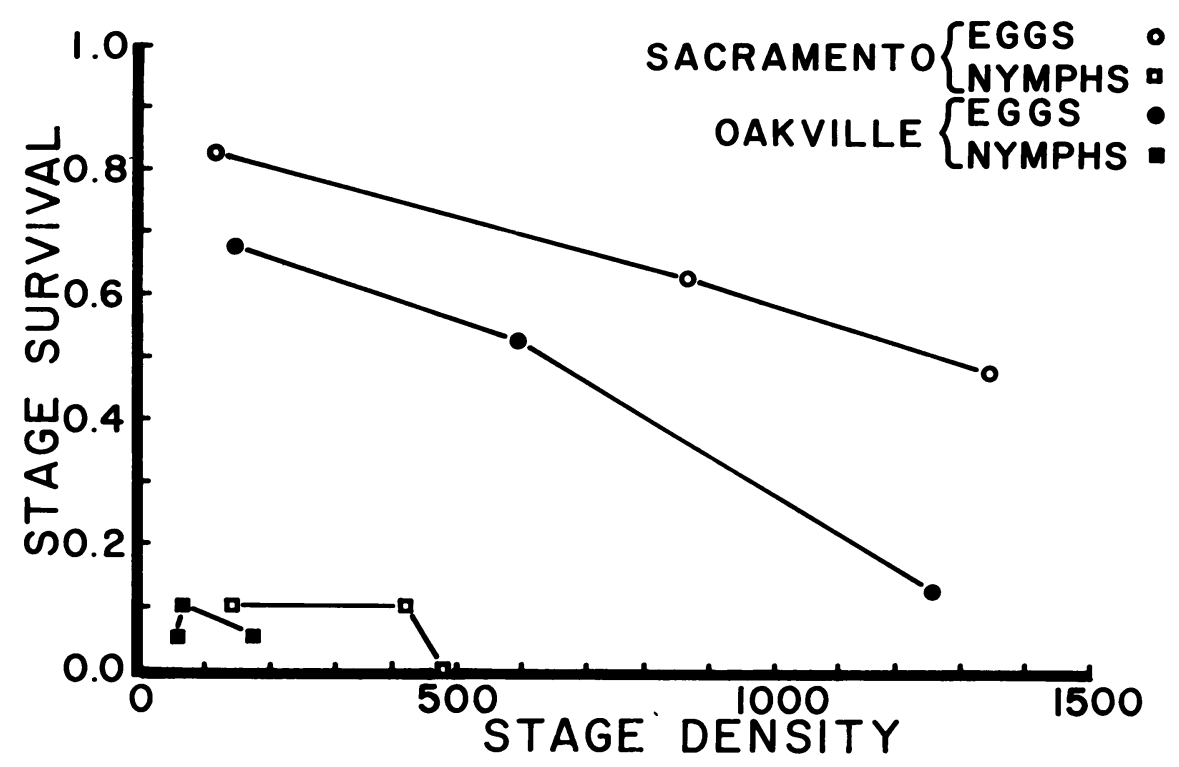

Fig. 12. Blackberry leafhopper egg and nymph survival plotted on density for the Sacramento and Oakville sites in 1979. The survival values are from the field life table analysis using the method of Kiritani and Nakasuji (1967), as modified by Manly (1976, 1977). The three connected points for each stage are, from left to right, the first, second, and third generations, respectively, indicating that density-dependent mortality increased through the season. The exception is the point closest to the origin, which represents the nymphs of the third generation in Oakville. In this case, a heavy egg mortality in the third generation produced a low nymph population, but general mortality was high because of the year's end build-up of natural enemies. 
throughout the season, with 30 percent of all eggs being deposited in the lowest stratum of the canopy, 32 percent in the second, 25 percent in the third, and 13 percent in the highest. The patterns of percent parasitization were also uniform throughout the season, with 25 percent of total parasitization in the lowest and second strata, 29 percent in the third, and 21 percent in the highest. The uniform seasonal distribution of BLH eggs and parasitism was likely influenced by the growth of the $R$. ursinus canopy, which remained thick and lush throughout most of the year because of the availability of water and partial shading.

Regression slopes for oviposition in $R$. procerus at Oakville (fig. 14a) are significantly positive. Oviposition shifted from the top to the bottom of the canopy through the season, with 15 percent of all oviposition occurring in the bottom half at the beginning of the year and 90 percent by the end. The rate of parasitism in the lower half of the canopy increased only 25 percent over the observation period of $3500^{\circ} \mathrm{D}$. At the beginning of the season, mean proportions of percent parasitization were $0.12,0.25,0.32$, and 0.31 , from the bottom of the canopy to the top, but they increased to $0.35,0.40,0.15$, and 0.10 by the end of the season. The early season prevalence of eggs in the upper strata of $R$. procerus
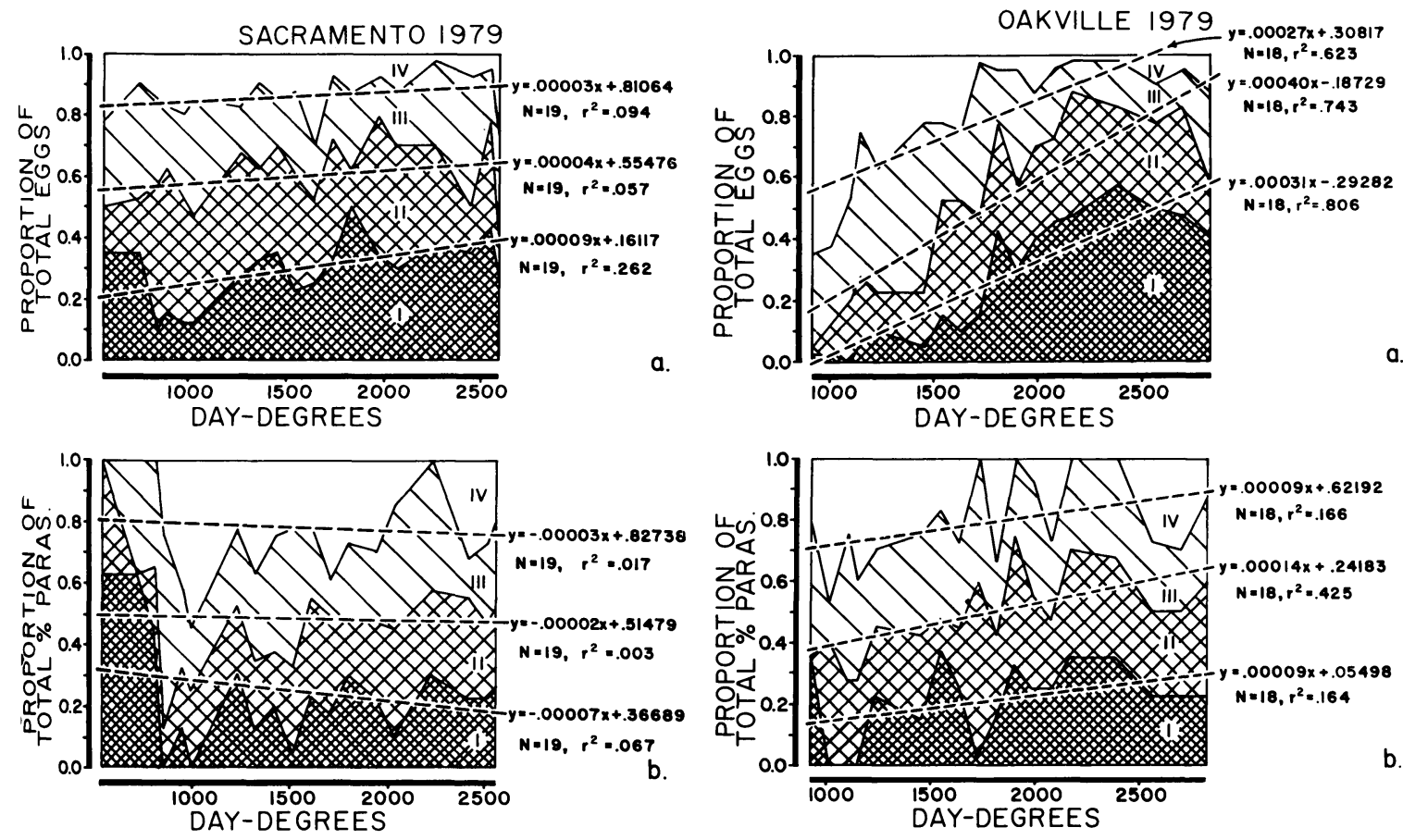

Fig. 13. Blackberry leafhopper oviposition and parasite activity in four levels of the blackberry canopy at Sacramento in 1979. Fig. 13a. The proportion of the total eggs found in each canopy stratum on sample dates throughout the growing season. Fig. 13b. The proportion of the total percentage of parasitization by Anagrus epos in each canopy stratum. The shaded area designated $I$ is the lowest stratum; II and III are successively higher; and $I V$ is the highest stratum.

Fig. 14. Blackberry leafhopper oviposition and parasite activity in four levels of the blackberry canopy at Oakville in 1979. Fig. 14a. The proportion of the total eggs found in each canopy stratum on sample dates throughout the growing season. Fig. 14b. The proportion of the total percentage of parasitization by Anagrus epos in each canopy stratum. The shaded area designated $I$ is the lowest stratum; II and III are successively higher; and $I V$ is the highest stratum. 
at the exposed Oakville site reflected a BLH preference for young leaves produced on rapidly growing canes at the periphery of the canopy. Later in the season, BLH adults moved into the canopy depths, perhaps to find a more favorable microhabitat.

Overall, the two host plant species in their different habitats provided very different environments for BLH, as reflected by oviposition patterns. Rubus ursinus, in the riparian habitat, had a more uniform seasonal canopy structure and BLH oviposited in a constant pattern within it, while $R$. procerus, in an exposed site, had a seasonally variable canopy and BLH oviposition patterns within it shifted through the season.

TABLE 8. MEAN DEVELOPMENT PERIODS IN DAYS OF BLH IMMATURE STAGES REARED AT A CONSTANT TEMPERATURE OF $24.1^{\circ} \mathrm{C}$

\begin{tabular}{lcccc}
\hline Stage & $\mathbf{N}$ & $\begin{array}{c}\text { Mean } \\
\text { duration }\end{array}$ & SD & $\begin{array}{c}\text { \% of total } \\
\text { immature period }\end{array}$ \\
\hline Egg & 93 & 12.3 & 0.685 & 44.3 \\
Instar I & 88 & $2.52 \mathrm{a}$ & 0.418 & 9.1 \\
Instar II & 70 & $2.69 \mathrm{a}$ & 0.585 & 9.7 \\
Instar III & 70 & $2.58 \mathrm{a}$ & 0.543 & 9.3 \\
Instar IV & 70 & $3.02 \mathrm{~b}$ & 0.507 & 10.9 \\
Instar V & 70 & $4.66 \mathrm{c}$ & 0.787 & 16.8 \\
\hline
\end{tabular}

NB. Means followed by the same letter are not significantly different at the 0.05 level, using Bonferroni's inequality.

TABLE 9. MEAN DEVELOPMENTAL TIMES IN DAYS AND DEGREE-DAYS FOR THE EGG AND SUMMED NYMPHAL PERIODS OF BLH AT FIVE TEMPERATURES

\begin{tabular}{|c|c|c|c|c|c|c|c|c|c|}
\hline $\begin{array}{l}\text { Temp } \\
\left({ }^{\circ} \mathrm{C}\right)\end{array}$ & $\mathbf{N}$ & $\begin{array}{c}\text { Mean } \\
\text { egg } \\
\text { duration } \\
\text { (days) }\end{array}$ & SD & $\begin{array}{c}\text { Mean } \\
\text { nymph } \\
\text { duration } \\
\text { (days) }\end{array}$ & SD & $\begin{array}{c}\text { Mean } \\
\text { egg } \\
\text { duration } \\
\left({ }^{\circ} \mathrm{D}>8.12^{\circ} \mathrm{C}\right)\end{array}$ & SD & $\begin{array}{c}\text { Mean } \\
\text { nymph } \\
\text { duration } \\
\left({ }^{\circ} \mathrm{D}>8.12^{\circ} \mathrm{C}\right)\end{array}$ & $\mathrm{SD}$ \\
\hline 13.2 & 17 & 38.8 & 1.690 & 69.3 & 9.59 & 197.7 & 8.61 & 354.3 & 48.93 \\
\hline 20.2 & 18 & 17.8 & 0.958 & 22.1 & 1.07 & 215.1 & 11.60 & 267.2 & 13.00 \\
\hline 24.1 & 91 & 12.3 & 0.692 & 15.5 & 0.768 & 196.6 & 11.07 & 248.8 & 12.28 \\
\hline 27.9 & 33 & 10.3 & 0.532 & 13.0 & 1.02 & 203.1 & 10.54 & 258.0 & 20.25 \\
\hline 30.0 & 17 & 9.59 & 0.618 & 13.0 & 0.919 & 210.0 & 13.54 & 284.7 & 20.12 \\
\hline \multicolumn{3}{|c|}{ All temperatures } & & & & 201.1 & 12.66 & 266.0 & 36.94 \\
\hline
\end{tabular}

TABLE 10. SUMMARY OF PARAMETERS OF LINEAR REGRESSIONS OF BLH AND ANAGRUS DEVELOPMENTAL, FEEDING, AND OVIPOSITION PROCESSES ON TEMPERATURE

\begin{tabular}{lccccc}
\hline \hline \multicolumn{1}{c}{ Process } & Slope (SE) & Intercept (SE) & $\mathbf{r}^{2}$ & $\mathbf{N}$ & $\begin{array}{c}\text { Threshold } \\
\left({ }^{\circ} \mathrm{C}\right)\end{array}$ \\
\hline BLH egg dev. rate & $0.0049(0.00009)$ & $0.0377(0.00208)$ & 0.949 & 176 & 7.74 \\
BLH total nymph dev. rate & $0.0040(0.00009)$ & $0.0338(0.00218)$ & 0.920 & 176 & 8.50 \\
BLH total nymph dev. rate* & $0.0043(0.00008)$ & $0.0411(0.00188)$ & 0.949 & 159 & 9.50 \\
$\begin{array}{l}\text { BLH preoviposition dev. rate } \\
\text { BLH adult feeding rate }\end{array}$ & $0.0086(0.00241)$ & $0.0830(0.05794)$ & 0.320 & 29 & 9.67 \\
$\quad$ (sq. cm/day) & $0.0047(0.00055)$ & $0.0627(0.01339)$ & 0.533 & 66 & 9.65 \\
\cline { 1 - 1 } & $0.0041(0.00012)$ & $0.0295(0.00281)$ & 0.869 & 187 & 7.20 \\
\hline
\end{tabular}

*Regression excluding high temperature $\left(30^{\circ} \mathrm{C}\right)$ data. 
Within host plants, the trends for BLH oviposition and parasitization were similar. The proportions of parasitized eggs were nearly equal among the four canopy strata at the Sacramento site, while they increased only slightly in the lower strata over the season at Oakville. The apparent evenness of parasitism within the $R$. ursinus canopy irrespective of BLH egg densities suggests that Anagrus females search uniformly within the canopy when conditions are favorable.

\section{Laboratory Studies of the Blackberry Leafhopper}

\section{Development of Immature Stages}

The mean duration of $\mathrm{BLH}$ immature stages at $24.1^{\circ} \mathrm{C}$ along with the mean proportions of the entire period spent in the egg and the nymphal stadia are given in table 8 . The egg stage is by far the longest of the developmental periods, while the first three instars are briefer and are not significantly different from each other in length. The durations of the fourth and fifth instars are significantly different and about 16 percent and 79 percent longer, respectively, than the means of the first three instars. Figure 15 depicts the five instars, which are distinguished by their general body size, wing bud lengths, and patterns of black dorsal setae.

Table 9 lists the average developmental times in days and ${ }^{\circ} \mathrm{D}$ for the egg and total nymphal periods at five temperatures. Consistent with the usual pattern for poikilotherm development, the time in days required to complete the egg stage decreased with increasing temperature. In contrast, the developmental periods for the summed nymphal stadia, while decreasing with increasing temperature at the three lower temperatures, were equal ( 13 days) at $27.9^{\circ}$ and $30.0^{\circ} \mathrm{C}$, suggesting that the upper thermal threshold for nymphal development may be near $30^{\circ} \mathrm{C}$. The retarding of development at high temperatures is common in poikilotherms (Andrewartha and Birch, 1954). Parameters of immature developmental rate regressions on temperature are listed in table 10 and the regression lines are plotted over the means of the constant temperature developmental rates in figure 16. (Note that

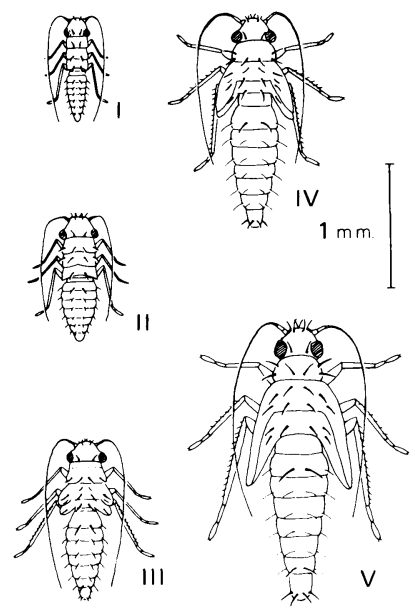

Fig. 15. The five nymphal instars of the blackberry leafhopper, Dikrella california (Lawson). The thick triangular dorsal setae are black, while the uniformly thin setae are unpigmented.

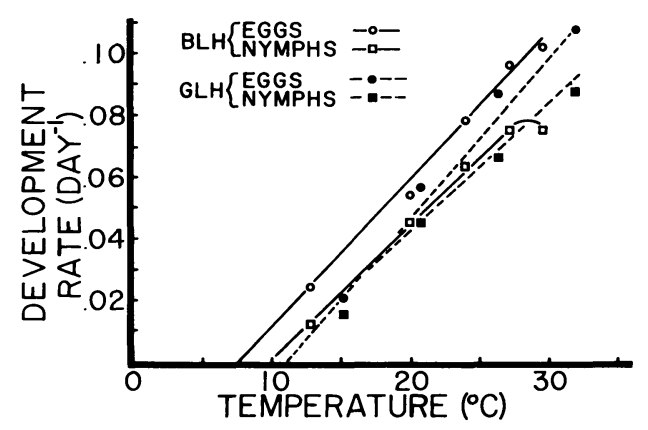

Fig. 16. A comparison of egg (circle) and nymph (square) developmental rates $\left(\right.$ day $^{-1}$ ) of blackberry leafhopper (open) and grape leafhopper (solid) plotted on temperature. 
similar regressions for the grape leafhopper are also shown in this figure [cf. Cate, 1975].) This figure reinforces the contrast in stage development patterns: the egg developmental rate curve is linear over the entire range of temperatures, while the nymph curve is linear up to $28^{\circ} \mathrm{C}$ and distinctly nonlinear beyond this temperature. The developmental threshold for the BLH egg $\left(7.74^{\circ} \mathrm{C}\right)$ is lower than that for the nymphal stages $\left(9.50^{\circ} \mathrm{C}\right)$. Since the estimation of the lower thermal threshold assumes linearity of the developmental rate with respect to temperature, the rate data for nymphs at $30^{\circ} \mathrm{C}$, which obviously lay outside the linear range, were excluded from the regression. The threshold used for BLH throughout this work $\left(8.12^{\circ} \mathrm{C}\right)$ is the average of the egg and nymphal thresholds.

\section{Fecundity and Longevity of the Blackberry Leafhopper}

Table 11 presents mean total fecundity, and preoviposition and reproductive periods in days and ${ }^{\circ} \mathrm{D}$ for $\mathrm{BLH}$ females at $20^{\circ}, 24^{\circ}$, and $28^{\circ} \mathrm{C}$. As with the egg and nymph data, the adult preoviposition and reproduction periods decreased with temperature. Average fecundities were nearly equal at $20^{\circ}$ and $24^{\circ} \mathrm{C}$ ( 72 to 74 eggs), while fecundity was considerably lower at $28^{\circ} \mathrm{C}$ ( 52 eggs). Although the differences were not significant at the 0.05 level, $28^{\circ} \mathrm{C}$ is probably close to the temperature detrimental to egg production and adult survival. These fecundity differences are apparent in figure 17, which presents regressions of cumulative oviposition on physiological time for the three temperature regimes. When the slopes of these regressions were subjected to three pairwise t-tests of differences, all three slopes were significantly different $(p<.05$ of a greater $t)$ from each other. The relatively low slope at $28^{\circ} \mathrm{C}(0.052$, versus 0.062 and 0.069$)$ and the shortened range of the total oviposition period $\left(1300^{\circ} \mathrm{D}\right.$, versus about $1700^{\circ} \mathrm{D}$ for the other two temperatures) reinforce the suggestion that this temperature is close to the upper thermal threshold for oviposition.

\section{Age-specific Life Tables for the Blackberry Leafhopper}

Age-specific life tables were constructed for BLH at the three temperatures according to the methods described in Andrewartha and Birch (1954). The survivorships ( $\left.1_{\mathrm{x}}\right)$, fecundities $\left(\mathrm{m}_{\mathrm{x}}\right)$, and net reproduction rates $\left(\mathrm{R}_{\mathrm{O}}\right)$ are shown plotted against physiological age in figure 18 .

The life table statistics $r_{m}, R_{O}$, and $T$ for $B L H$, calculated on the basis of days and ${ }^{\circ} \mathrm{D}\left(>8.12^{\circ} \mathrm{C}\right)$, are given in table 12 . On the day basis, $\mathrm{r}_{\mathrm{m}}$ increased and $\mathrm{T}$ decreased

TABLE 11. PREOVIPOSITION PERIOD, REPRODUCTIVE LONGEVITY, AND FECUNDITY OF BLH FEMALES AT THREE CONSTANT TEMPERATURES

\begin{tabular}{|c|c|c|c|c|c|c|c|c|c|c|c|}
\hline $\begin{array}{l}\text { Temp } \\
\left({ }^{\circ} \mathrm{C}\right)\end{array}$ & $\mathbf{N}$ & $\begin{array}{c}\text { Pre- } \\
\text { oviposition } \\
\text { period } \\
\text { (days) }\end{array}$ & $\mathrm{SD}^{\circ}$ & $\begin{array}{r}\text { Pre- } \\
\text { ovipositi } \\
\text { period } \\
\\
\mathrm{D}>8.12\end{array}$ & SD & $\begin{array}{c}\text { Repro- } \\
\text { ductive } \\
\text { longev- } \\
\text { ity } \\
\text { (days) }\end{array}$ & SD & $\begin{array}{c}\text { Repro- } \\
\text { ductive } \\
\text { longev- } \\
\text { ity } \\
\mathrm{D}>8.12^{\circ}\end{array}$ & $\begin{array}{l}\text { SD } \\
\text { C) }\end{array}$ & $\begin{array}{l}\text { Fecund- } \\
\text { ity }\end{array}$ & SD \\
\hline 20 & 9 & 11.7 & 3.63 & 138.8 & 43.21 & 94.4 & 39.9 & 1123.9 & 474.3 & 74.0 & 44.9 \\
\hline 24 & 12 & 9.32 & 2.72 & 148.1 & 43.32 & 62.1 & 30.9 & 987.4 & 490.8 & 72.3 & 45.6 \\
\hline 28 & 8 & 6.75 & 2.12 & 134.3 & 42.21 & 39.8 & 11.0 & 791.0 & 218.2 & 52.0 & 26.5 \\
\hline Mean & 29 & - & - & 141.4 & 41.86 & - & - & 975.6 & 433.2 & - & - \\
\hline
\end{tabular}


with temperature. Net reproductive rates were the same for days or ${ }^{\circ} \mathrm{D}$; they were uniform (ca 67.0) at $20^{\circ}$ and $24^{\circ} \mathrm{C}$, but dropped dramatically (to 46.26 ) at $28^{\circ} \mathrm{C}$, again indicating the detrimental effects of high temperature. Generation times on a ${ }^{\circ} \mathrm{D}$ basis were almost equal (ca $1140^{\circ} \mathrm{D}$ ) at the lower temperatures, but fell $\left(913^{\circ} \mathrm{D}\right)$ at the highest. Intrinsic rates of increase were remarkably uniform for all temperatures on a physiological time basis (ca 0.0046), masking the effects of high temperatures on fecundity. Because $r_{m}$ is approximated as $1 \mathrm{n} \mathrm{R}_{\mathrm{O}} / \mathrm{T}$, a lowered $\mathrm{R}_{\mathrm{O}}$ can be compensated by a shortened $\mathrm{T}$. This phenomenon is well illustrated at $28^{\circ} \mathrm{C}$, where both $\mathrm{R}_{\mathrm{O}}$ and $\mathrm{T}$ decreased compared with their values at $20^{\circ}$ and $24^{\circ} \mathrm{C}$, and $\mathrm{r}_{\mathrm{m}}(0.0048)$ remained almost equal to that at the two lower temperatures. These results clearly show the importance of early reproduction and short generation times on population growth rates and further illustrate the lessened contribution of reproduction late in the life cycle to $\mathrm{r}_{\mathrm{m}}$ (Birch, 1948 and Lewontin, 1965).

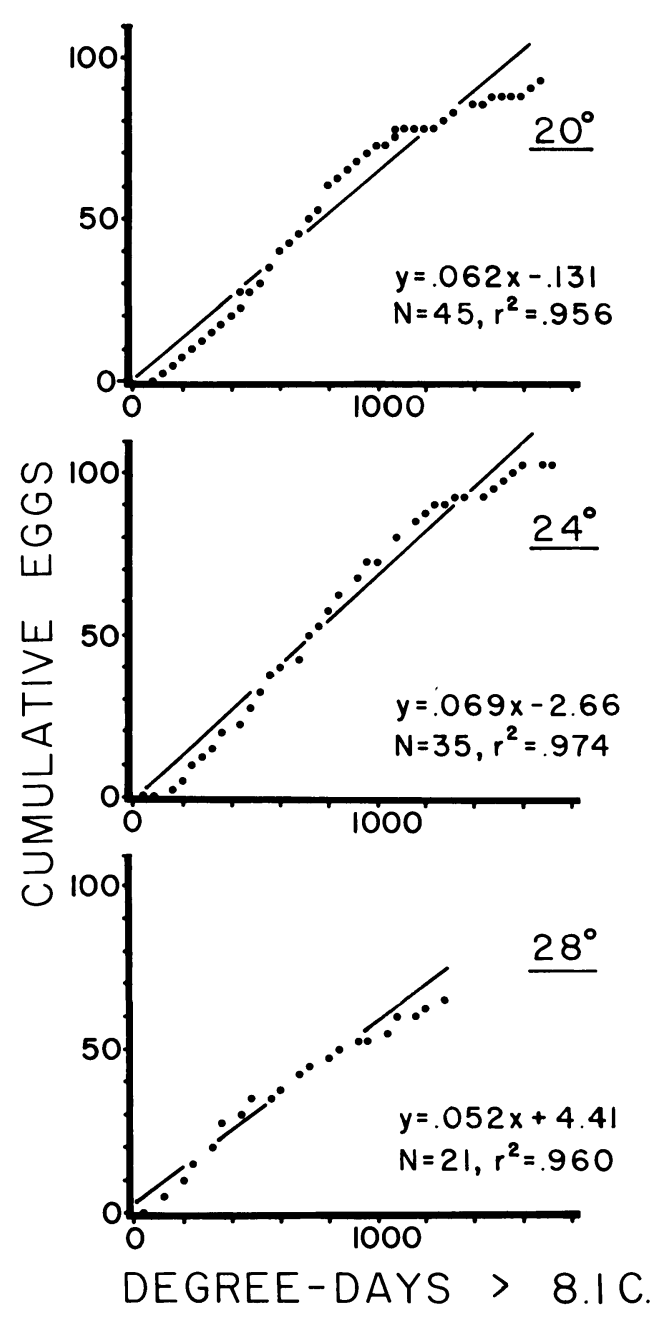

Fig. 17. Cumulative oviposition per female plotted on a physiological time scale $\left({ }^{\circ} \mathrm{D}>8.12^{\circ} \mathrm{C}\right)$ for blackberry leafhopper females at three constant temperatures in the laboratory. Top, $20^{\circ} \mathrm{C}$; 9 individuals. Center, $24^{\circ} \mathrm{C} ; 12$ individuals. Bottom, $28^{\circ} \mathrm{C} ; 8$ individuals. 


\section{Feeding Rate of the Blackberry Leafhopper}

Feeding rates of $\mathrm{BLH}$ adults at three constant temperatures are given in table 13 . The rates increase with temperature, but they more than double between $23^{\circ}$ and $28^{\circ} \mathrm{C}$. The data suggest an exponential increase in feeding rate $(\mathrm{Y})$ with temperature $(\mathrm{T})$ and are fitted by

$$
\mathrm{Y}=\exp (0.0943 \mathrm{~T}-5.39)
$$

Parameters for the linear regression of feeding rate on temperature are given in table 10 . Although the experimental methods and variables measured here were different from those in the developmental rate studies, it is reassuring that the feeding threshold $\left(9.65^{\circ} \mathrm{C}\right)$ is close to the developmental threshold for nymphs.

The total leaf surface area destroyed during the nymphal period was estimated to be $0.218 \mathrm{~cm}^{2}(\mathrm{~s}=0.0303, \mathrm{~N}=22)$. If the rate of feeding is assumed to be linear throughout the whole nymphal period $\left(226^{\circ} \mathrm{D}\right)$, a crude exponential model can be developed. Unfortunately, the model underestimates leaf area killed by early instars, possibly because whole cells are killed regardless of the size of the insect feeding. Feeding rate is really a function of nymph size, but the age-size relationship is not known, and hence, a linear model of leaf area removal rate as a function of age was used. Since the leaf area damaged during the entire nymphal period was estimated to be $0.218 \mathrm{~cm}^{2}$, cumulative feeding damage was easily modeled as

$$
\mathrm{y}=.0000031 \mathrm{a}^{2},
$$

where $\mathrm{y}=$ total leaf area destroyed and $\mathrm{a}=$ age in ${ }^{\circ} \mathrm{D}$. Using this simple model, the areas estimated to be destroyed by instars I through $\mathrm{V}$ are $0.006,0.019,0.031,0.053$, and 0.109 $\mathrm{cm}^{2}$, respectively.
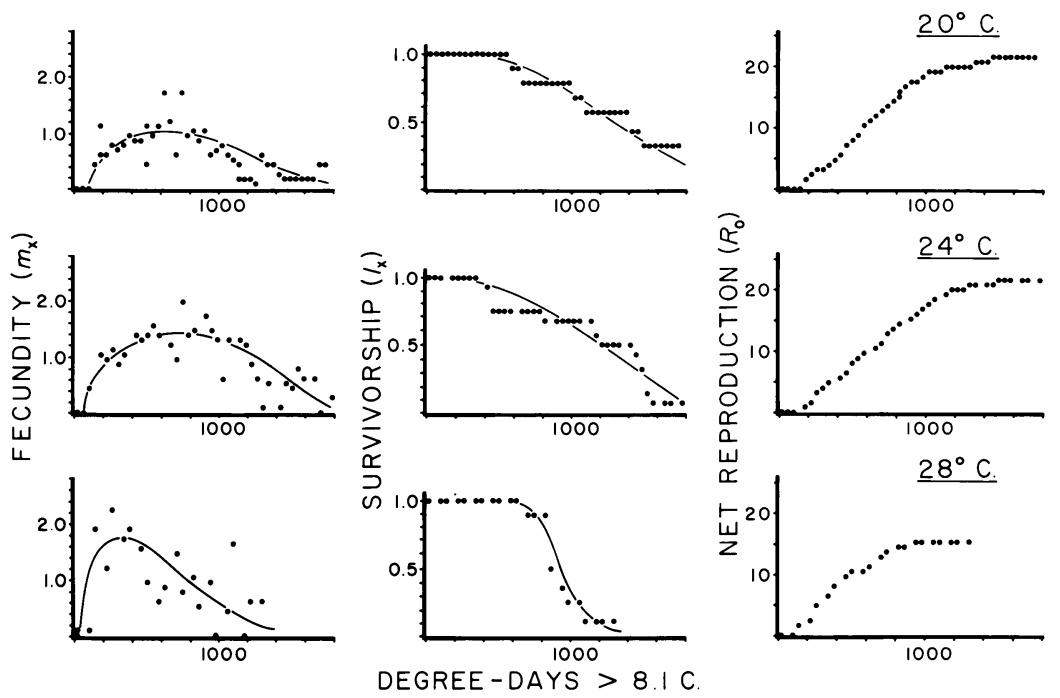

Fig. 18. Fecundity $\left(\mathrm{m}_{\mathrm{x}}\right)$, survivorship $\left(\mathrm{l}_{\mathrm{x}}\right)$, and net reproduction $\left(\mathrm{R}_{\mathrm{O}}\right)$ from the age-specific life table study of the blackberry leafhopper at three constant temperatures, plotted on physiological time $\left({ }^{\circ} \mathrm{D}>8.12^{\circ} \mathrm{C}\right) . \mathrm{N}=9$ females at $20^{\circ} \mathrm{C} ; \mathrm{N}=12$ at $24^{\circ} \mathrm{C} ; \mathrm{N}=8$ at $28^{\circ} \mathrm{C}$. All curves are eye-fitted. 


\section{Laboratory Studies of Anagrus epos}

\section{Immature Development}

Total immature development times (that is, from oviposition to adult emergence) for Anagrus at three temperatures are given in table 14. The development periods in days decreased with increasing temperature, but the mean periods in physiological time were remarkably close, averaging $244.5^{\circ} \mathrm{D}$. Variability increased with temperature, as indicated by the CVs, which ranged from 3.7 to 11.9 . The increase resulted from the use of a constant 1-day observation interval at all temperatures. Had the observation intervals decreased with increasing temperatures (that is, to maintain approximately equal physiological time intervals), the CVs likely would have been much closer.

The developmental threshold of Anagrus $\left(7.16^{\circ} \mathrm{C}\right)$ does not differ significantly from that of the BLH egg, contradicting the hypothesis proposed by Campbell et al. (1974) that a parasite's threshold should be higher than that of its host. This possibly occurs because Anagrus attacks many leafhoppers and is not necessarily closely adapted to BLH.

TABLE 12. INTRINSIC RATES OF INCREASE $\left(\mathrm{r}_{\mathrm{m}}\right)$, NET REPRODUCTIVE RATES $\left(\mathrm{R}_{\mathrm{o}}\right)$,

AND GENERATION TIMES (T) FOR BLH AND ANAGRUS AT THREE CONSTANT

TEMPERATURES AND FOR GLH AT $21.1^{\circ} \mathrm{C}$ (J. R. CATE, UNPUBL. DATA $)$, CALCULATED

ON THE BASIS OF DAYS AND DEGREE-DAYS. BLH THRESHOLD $=8.12^{\circ} \mathrm{C}$; ANAGRUS THRESHOLD $=7.2^{\circ} \mathrm{C} ;$ AND GLH THRESHOLD $=10.3^{\circ} \mathrm{C}$

\begin{tabular}{lccccccc}
\hline \hline \multirow{2}{*}{ Species } & \multirow{2}{*}{$\begin{array}{c}\text { Temp } \\
\left({ }^{\circ} \mathbf{C}\right)\end{array}$} & \multicolumn{3}{c}{ Based on days } & \multicolumn{3}{c}{ Based on degree-days } \\
\cline { 3 - 8 } \cline { 4 - 8 } & 20 & $\mathbf{r}_{\mathbf{m}}$ & $\mathbf{R}_{\mathbf{o}}$ & $\mathbf{T}$ & $\mathbf{r}_{\mathbf{m}}$ & $\mathbf{R}_{\mathbf{o}}$ & \multicolumn{1}{c}{$\mathbf{T}$} \\
\hline \multirow{3}{*}{$\mathrm{BLH}$} & 24 & 0.0732 & 66.84 & 96.6 & 0.0044 & 66.84 & 1149.6 \\
& 28 & 0.0947 & 46.26 & 45.9 & 0.0048 & 46.26 & 913.3 \\
\hline \multirow{3}{*}{ Anagrus } & 18 & 0.1060 & 14.25 & 25.3 & 0.0098 & 14.25 & 272.3 \\
& 23 & 0.1780 & 20.17 & 17.1 & 0.0113 & 20.17 & 269.6 \\
& 28 & 0.1650 & 10.50 & 14.4 & 0.0079 & 10.50 & 300.1 \\
\hline \multirow{2}{*}{ GLH } & 21.1 & 0.0495 & 19.88 & 62.1 & 0.0046 & 19.88 & 672.7 \\
\hline
\end{tabular}

TABLE 13. FEEDING RATES ( $\mathrm{CM}^{2}$ OF LEAF PER DAY) OF BLH ADULTS AT THREE CONSTANT TEMPERATURES

\begin{tabular}{cccc}
\hline \hline $\begin{array}{c}\text { Temperature } \\
\left({ }^{\circ} \mathrm{C}\right)\end{array}$ & $\mathbf{N}$ & Mean rate & SD \\
\hline 18 & 17 & 0.0278 & 0.0110 \\
23 & 17 & 0.0316 & 0.0126 \\
28 & 32 & 0.0714 & 0.0207 \\
\hline
\end{tabular}

TABLE 14. TOTAL IMMATURE DEVELOPMENT TIMES FOR ANAGRUS EPOS AT THREE CONSTANT TEMPERATURES

\begin{tabular}{cccccc}
\hline \hline $\begin{array}{c}\text { Temperature } \\
\left({ }^{\circ} \mathrm{C}\right)\end{array}$ & $\mathbf{N}$ & $\begin{array}{c}\text { Mean time } \\
\text { (days) }\end{array}$ & SD $(\mathrm{CV})$ & $\begin{array}{c}\text { Mean time } \\
\left({ }^{\circ} \mathrm{D}>7.16^{\circ} \mathrm{C}\right)\end{array}$ & SD \\
\hline 18 & 54 & 22.5 & $0.823(3.7)$ & 244.3 & 8.925 \\
23 & 62 & 15.3 & $1.110(7.3)$ & 242.5 & 17.64 \\
28 & 71 & 11.8 & $1.400(11.9)$ & 246.4 & 29.21 \\
\hline
\end{tabular}




\section{Fecundity and Longevity of Anagrus}

Table 15 presents fecundity and longevity means for Anagrus at three temperatures. In contrast to leafhopper adults, the parasite does not have a long preoviposition period. Fecundity dropped dramatically between $23^{\circ}$ and $28^{\circ} \mathrm{C}$ (that is, from 20.2 eggs to only 9.8 eggs). The differences were not significant, but the trends were similar to those of BLH. While longevity in days decreased with temperature as expected, the means on a physiological time scale were not consistent. The high variability observed in these experiments was due to the fragile nature of the parasite adults, some of which were injured during transfers between cages. Further error was introduced because of small sample sizes. This was unavoidable because the parasite is tiny (ca. $1 \mathrm{~mm}$ long) and handling is tedious and time-consuming.

\section{Age-specific Life Tables for Anagrus}

Figure 19 presents $\mathrm{m}_{\mathrm{x}}, \mathrm{l}_{\mathrm{x}}$, and $\mathrm{R}_{\mathrm{O}}$ curves on ${ }^{\circ} \mathrm{D}$ at $18^{\circ}, 23^{\circ}$, and $28^{\circ} \mathrm{C}$. Life table parameters on day and ${ }^{\circ} \mathrm{D}$ bases are compared in table 12 . Generation times decreased with temperature on a day basis, as anticipated, and were similar on a physiological time basis (ca $280^{\circ} \mathrm{D}$ ). Both $r_{m}$ and $R_{o}$ values were highest at $20^{\circ} \mathrm{C}$ and fell off at higher and lower temperatures when calculated on a ${ }^{\circ} \mathrm{D}$ basis. While one expects the deleterious effects of high temperature, the loss of reproductive potential at low temperature is puzzling, since $18^{\circ} \mathrm{C}$ should not be so low as to produce nonlinear effects in development or oviposition rates. It is likely due partially to experimental error, as examination of the $1_{\mathrm{x}}$ curves (fig. 19) reveals an earlier onset of mortality at $18^{\circ} \mathrm{C}$ than at either of the other temperatures.

A comparison of Anagrus and BLH life table parameters at $23^{\circ}$ and $24^{\circ} \mathrm{C}$, respectively, on a ${ }^{\circ} \mathrm{D}$ basis (see table 12 ) shows that the $\mathrm{r}_{\mathrm{m}}$ of Anagrus $(0.0113$ ) is about 2.2 times that of BLH (0.0046). The comparison could be made only at $23^{\circ}$ and $24^{\circ} \mathrm{C}$ because of the small difference between these temperatures and because of the discrepancies in the high and low temperature Anagrus data. The difference in $\mathrm{r}_{\mathrm{m}}$ reflects the short generation time $\left(270^{\circ} \mathrm{D}\right)$ of Anagrus relative to that of $\mathrm{BLH}\left(1130^{\circ} \mathrm{D}\right)$ and its reproduction early in the life cÿcle.

\section{Parasite Mating Behavior and Sex Ratio}

Courtship behavior appears to be minimal in Anagrus. When two recently emerged adults were placed in an aspirator, they ran about until making physical contact. Then, the male pursued the female and touched her dorsally with his antennae. This act generally arrested the female and the male mounted her dorsally from behind, bending the tip of his

TABLE 15. REPRODUCTIVE LONGEVITY AND FECUNDITY IN DAYS AND DEGREE-DAYS FOR ANAGRUS EPOS AT THREE CONSTANT TEMPERATURES

\begin{tabular}{ccccccccc}
\hline \hline $\begin{array}{c}\text { Temperature } \\
\left({ }^{\circ} \mathrm{C}\right)\end{array}$ & $\mathbf{N}$ & $\begin{array}{c}\text { Longevity } \\
\text { (days) }\end{array}$ & SD & $\begin{array}{c}\text { Longevity } \\
\left({ }^{\circ} \mathbf{D}>7.16^{\circ} \mathrm{C}\right)\end{array}$ & SD & N & $\begin{array}{c}\text { Fecund- } \\
\text { ity }\end{array}$ & SD \\
\hline 18 & 8 & 8.1 & 4.02 & 87.8 & 43.4 & 8 & 14.3 & 14.1 \\
23 & 7 & 7.9 & 2.12 & $124.4^{*}$ & 33.4 & 6 & 20.2 & 12.2 \\
28 & 8 & 3.6 & 2.26 & $75.4^{*}$ & 47.1 & 6 & 9.83 & 6.85 \\
\hline
\end{tabular}

*Means significantly different at the 0.05 level by a t-test of differences. 
abdomen anteriorly to contact her genital opening. In some cases, the initial contact was sufficient to arrest a female. Copulation rarely continued more than one minute.

While arrhennotoky is common in parasitic Hymenoptera and is likely in $A$. epos, thelytoky is known in the genus Anagrus (Walker, 1979). The conclusion of arrhennotoky for $A$. epos is supported by the presence of males in the laboratory and field. Females exposed to males and producing male offspring yielded 51 percent females on average in the laboratory, although high variability was observed $(s=0.208 ; N=23)$. In sharp contrast, unmated females produced only males in these studies. Material collected in the field and reared in the laboratory (June to July 1980) yielded an average of 52 percent females from 75 eggs on six collection dates $(s=0.071)$. Thus, the field and laboratory sex ratios were remarkably similar, although sample sizes were rather small.

\section{DISCUSSION}

\section{Ecology of the Blackberry Leafhopper and the Two Blackberry Species}

Both Rubus ursinus and $R$. procerus are rapidly growing hardy plants that, although sometimes found growing together, generally occupy different habitats. Rubus ursinus grows in semishaded areas with plentiful water (riparian habitats), while $R$. procerus is drought tolerant and most often found in open sunny areas, such as pastures. The growth habits of the two species reflect their habitat preferences. Rubus ursinus has weak, slender canes that climb over bushes and trees, while $R$. procerus has stout canes that facilitate the construction of self-supported brambles in open locations. Despite the structural differences of the brambles, the two species accumulate leaf area at about the same rate and have similar Leaf Area Index limits.
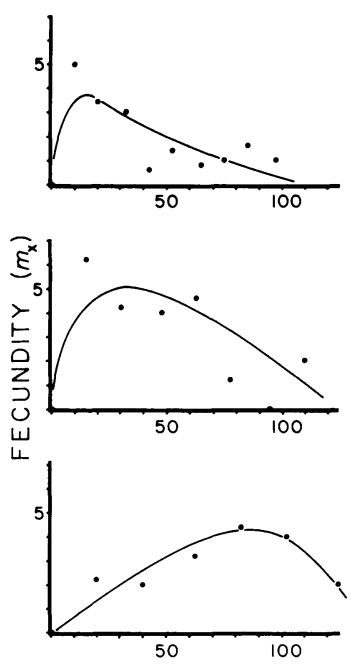
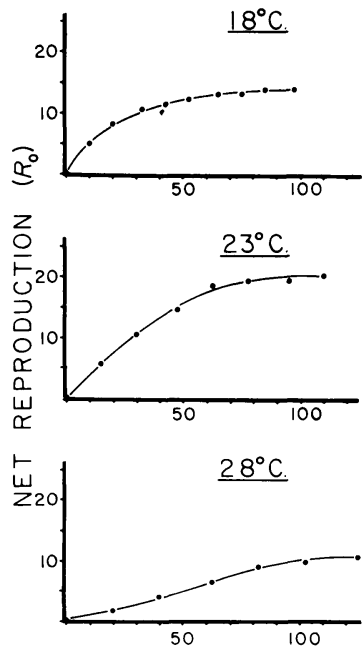

Fig. 19. Fecundity $\left(m_{x}\right)$, survivorship $\left(1_{x}\right)$, and net reproduction $\left(R_{o}\right)$ from the age-specific life table study of Anagrus epos at three constant temperatures plotted on physiological time $\left({ }^{\circ} \mathrm{D}>7.2^{\circ} \mathrm{C}\right)$. $\mathrm{N}=8$ females at $18^{\circ} \mathrm{C} ; \mathrm{N}=6$ at $23^{\circ} \mathrm{C} ; \mathrm{N}=4$ at $28^{\circ} \mathrm{C}$. All curves are eye-fitted. 
Rubus ursinus is determinate in its growth, as the timing of budbreak, maximum canopy development, and initiation of tip-rooting are well defined and uniform for all canes seasonally. In contrast, $R$. procerus is less determinate, since primocanes arise throughout the season and those appearing late in the season sometimes grow vigorously late into the fall. In general, $R$. ursinus, a native plant, is closely adapted to and limited by the California climate, while $R$. procerus, a recent import from Europe and a very successful weed, appears less constrained.

The blackberry leafhopper is well synchronized with $R$. ursinus, as BLH populations enter diapause during canopy decline and the onset of dormancy, and terminate diapause just before the flush of leaves in early spring. On $R$. procerus BLH initiates adult diapause during canopy decline, but terminates it long before budbreak, showing a lack of adaptation. Since BLH was not monitored on both species at one location however, these observations must be regarded with reservation. After oviposition begins in spring, BLH adults respond differently to the two blackberry species: in $R$. ursinus, they oviposit in the lower half of the canopy during the entire season, while in $R$. procerus, they shift oviposition from the top of the canopy to the bottom seasonally. This is probably due both to high temperature effects at the exposed Oakville site and to changing food quality.

Because of its synchrony with BLH, Rubus ursinus is clearly the preferable blackberry species for artificial refuges, but unfortunately it does not grow successfully outside the riparian habitat or requires excessive amounts of water and shading. Rubus procerus, while not as well synchronized with BLH, grows vigorously around vineyards and is likely to be used most often for refuges. Regardless of the species employed, the bramble must be manipulated in such a way as to assure high BLH oviposition and survival. Maintenance of the necessary lush canopy will require irrigation and annual pruning to keep the bramble in a vegetative (primocene) phase of growth. H. Kido and D. L. Flaherty (UC, Davis, and UC Cooperative Extension, respectively, personal communication) have produced lush canopies in $R$. procerus and thereby enhanced BLH (and Anagrus) populations by mowing halves of refuges in alternate years.

Another consideration for refuge implementation is the maintenance of BLH populations. In this study, immature mortality was high due to Anagrus parasitization and to predation and parasitization of nymphs. Since artificial refuges are small islands supporting finite BLH populations in an effectively limitless vineyard environment, leafhopper populations will suffer extinctions periodically, whether due to massive feedback of Anagrus from the vineyard in the late season (as observed at the Oakville site), general predation, or insecticide drift. To work as intended, refuges will require regular monitoring of BLH populations, and occasional reintroductions when populations are low or extinct.

\section{Linkage of the Refuge System with the Vineyard System}

\section{A Comparison of the Blackberry and Grape Leafhoppers}

Blackberry leafhopper and grape leafhopper are similar in size, behavior, and physiology (cf. Cate, 1975). Except for the BLH egg regression, the developmental rate curves (fig. 16) are remarkably alike, with similar slopes and thresholds. While the slope of the BLH egg curve is near the other three, the estimated threshold is about $3^{\circ} \mathrm{C}$ lower. If the difference is real, it enables BLH to develop during the cool early spring. The high temperature threshold of the BLH nymphal curve is lower than that of its egg stage and those of GLH immatures, and this may constitute a critical microclimate constraint for BLH. 
Age-specific life table analyses (table 12) show the net reproduction rate $\left(R_{\mathrm{O}}\right)$ of the blackberry leafhopper (ca 67.0) to be over three times that of the grape leafhopper (19.88), while the total generation time $\left(1140^{\circ} \mathrm{D}\right.$ above $\left.8.1^{\circ} \mathrm{C}\right)$ of $\mathrm{BLH}$ is twice that of GLH $\left(673{ }^{\circ} \mathrm{D}\right.$ above $\left.10.3^{\circ} \mathrm{C}\right)$. It is interesting that $\mathrm{r}_{\mathrm{m}} \mathrm{s}$ for the two species are equal $(.0046)$ when calculated on a physiological time basis.

The grape leafhopper like BLH is closely synchronized with its host. It starts oviposition as many as 6 to 8 weeks later than BLH as a result of the later budbreak in grape. In part due to evolved photoperiod responses, GLH initiates diapause in August, nearly 3 weeks before BLH. Field generation times are difficult to compare because of differences in thresholds and developmental rates among the stages and species, but overall they are similar. Due to the shorter growing season in grape, Cate (1975) observed only two complete GLH generations at St. Helena in the Napa Valley in 1972-73. Under almost identical climatic conditions ( season lengths in ${ }^{\circ} \mathrm{D}$ ) at Oakville, BLH produced three broods in 1979.

\section{Parasitization by Anagrus epos}

The synchrony of blackberry leafhopper, grape leafhopper, and Anagrus phenology reported by Doutt and Nakata (1973) was verified in this study at the Sacramento (riparian) site in 1979 and 1980. Wild grape leaf growth and spring oviposition by GLH followed

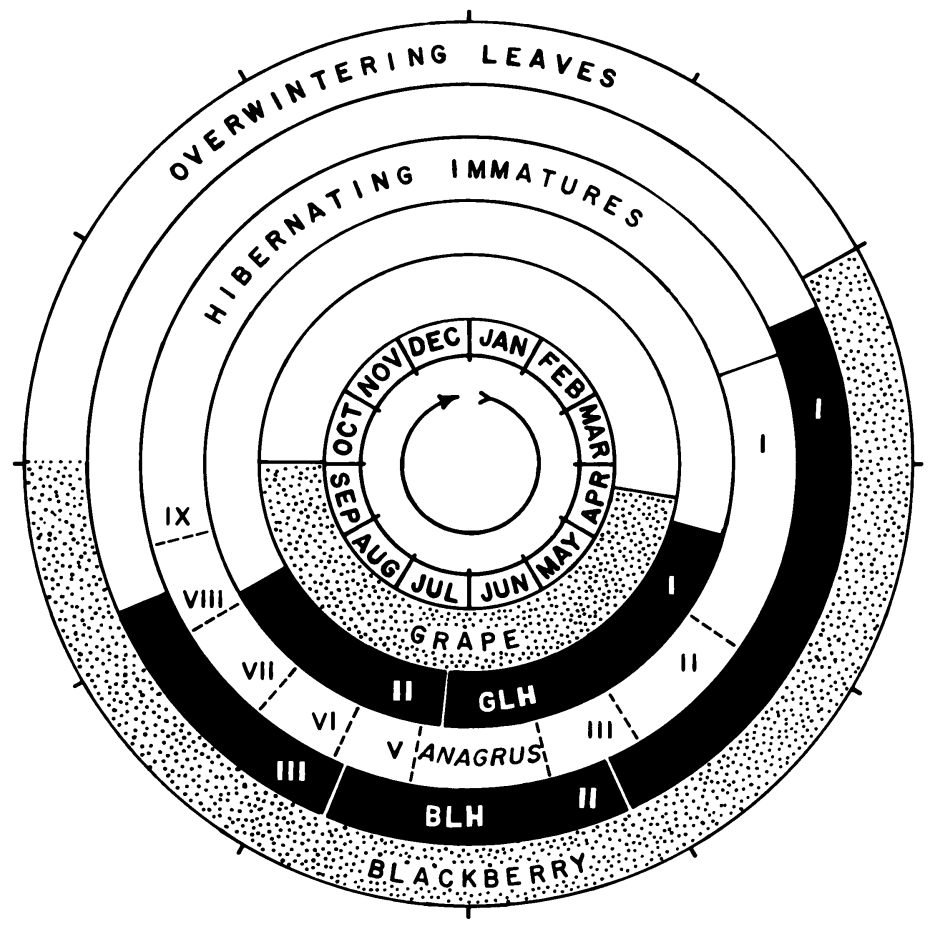

Fig. 20. Phenological relationships of wild grape, blackberry, the grape leafhopper (GLH), the blackberry leafhopper (BLH), and Anagrus epos in the riparian habitat. The stippled area for grape is the period during which the vine has leaves, while that for blackberry represents the time of active leaf production. Roman numerals represent generations of the respective insect species. Both leafhopper species overwinter as diapausing adults, while Anagrus hibernates in its immature stages in BLH eggs in overwintering blackberry leaves. Note that Anagrus develops its first generation on BLH eggs before GLH eggs are available for attack. 
the blackberry flush and BLH oviposition by about $195^{\circ} \mathrm{D}$ (somewhat less than one Anagrus generation of $244^{\circ} \mathrm{D}$ ). Hence, Anagrus emerged from hibernation at the time of BLH oviposition and increased its populations for one generation in blackberry before attacking grape leafhopper. Figure 20 shows the seasonal cycle for the five-species system in the riparian habitat. Since many commercial grape cultivars break buds later in the season than Vitis californica (for example, up to 3 to 4 weeks later in Cabernet sauvignon [McIntyre et al., 1982]) the potential for Anagrus augumentation may be greater in vineyards than in the wild system.

The regulative ability of Anagrus is difficult to assess, as seasonal percentages of parasitization in both leafhopper species, while impressive in their magnitude, do not provide a good index of parasite control. The only definitive method for assessing a natural enemy's effectiveness in controlling its host is an exclusion experiment in the field (DeBach and Huffaker, 1971), but such an experiment was not undertaken in this study. Since the ability to respond rapidly to increases in host density is a better index than percent parasitization, intrinsic rates of increase of the hosts and parasite were compared. On a ${ }^{\circ} \mathrm{D}$ basis, Anagrus's $r_{m}$ is about twice those of GLH and BLH (table 18). If the initial parasite population levels are reasonably high each year due to an influx from refuges, such differences in $r_{m}$ should confer upon Anagrus a fast responsiveness to changes in GLH density. From a purely theoretical standpoint, May (1975) has shown simple predator-prey systems modeled with Lotka-Volterra equations to be unstable under such conditions when a prey species' carrying capacity is considerably larger than that of its predator's (as may be the case in the GLHAnagrus system). A better assessment of grape agroecosystem stability ás it is affected by the dynamics of the blackberry-BLH-Anagrus system will be gained by the analysis of a simulation model. This analysis is beyond the scope of the present study and will be pursued in a future paper.

\section{ACKNOWLEDGMENTS}

I thank A. P. Gutierrez who offered valuable advice through the various phases of this study, and provided generously of his time and editorial skills in reviewing the manuscript. In addition, I thank C. B. Huffaker and R. K. Colwell who reviewed an earlier version of the manuscript. I greatly appreciate the cooperation of the Christian Brothers Winery for permitting me to work in and around their Oakville vineyard. I am grateful to A. H. Purcell, H. Kido, and J. Nakata for their advice in the initial phase of this investigation, to R. J. Gill and J. Lattin for their help in identifying insects encountered in the study, and to Mrs. Betty Pennington for her swift and skillful typing of the manuscript. This reasearch was supported in part by the National Science Foundation through grant NSF DEB-77-25260.

The University of California in compliance with the Civil Rights Act of 1964, Title IX of the Education Amendments of 1972, and the Rehabilitation Act of 1973 does not discriminate on the basis of race, creed, religion, color, national origin, sex, or mental or physical handicap in any of its programs or activities, or with respect to any of its employment policies, practices, or procedures. The University of California does not discriminate on the basis of age, ancestry, sexual orientation, marital status, citizenship, nor because individuals are disabled or Vietnam.era veterans. Inquiries regarding this policy may be directed to the Affirmative Action Officer, 2120 University Ave., University of California, Berkeley, California 94720 (415) 644-4270. 